\title{
Zgromadzenie Sióstr Felicjanek w Tarnowie w latach 1869-1992
}

\author{
Doktorant PAWE€ GLUGLA \\ Wydział Socjologiczno-Historyczny \\ Uniwersytet Rzeszowski
}

W ciągu wieków wiele zgromadzeń zakonnych miało i ma nadal swoje domy w Tarnowie. Jednym z nich były siostry felicjanki ${ }^{1}$. Zgromadzenie Sióstr Świętego Feliksa z Kantalicjo Trzeciego Zakonu Regularnego Świętego Franciszka Serafickiego, czyli siostry felicjanki ${ }^{2}$, Congregatio Sororum Sancti Felicis de Cantalice Tertii Ordinis Regularis Sancti Francisci Seraphici ${ }^{3}$, jako żeńskie zgromadzenie zakonne,

${ }^{1}$ Por. H. Czernigiewicz, Felicjanki, [w:] Encyklopedia katolicka, t. 5, red. P. Hemperek i in., Lublin 1989, kol. 100-103.

${ }^{2}$ Nazwę „felicjanki”, używaną od pierwszych lat istnienia zgromadzenia, zaczerpnięto od patrona zgromadzenia i jego ołtarza w bocznej kaplicy warszawskiego kościoła kapucynów, przy którym modliły się pierwsze siostry z podopiecznymi. Kapucyn, św. Feliks z Cantalicio (1515-1587), jest patronem dzieci. Podczas ekstaz miał otrzymywać od Maryi do piastowania dzieciątko Jezus. Olejem, który wykradał z wiecznej lampki, namaszczał chore niemowlęta, które powracały do zdrowia. Obrzęd namaszczania olejem poświęconym ku czci tegoż świętego praktykuje się w kościołach kapucyńskich w dzień świętego, każdego roku w dniu 18 maja. Por. J. Marecki, Zakony żeńskie w Polsce, Kraków 1997, s. 31-32.

${ }^{3}$ H. Czernigiewicz, Felicjanki, dz. cyt., kol. 101. 
założone zostało 21 listopada 1855 roku w Warszawie za zezwoleniem bpa Antoniego Melchiora Fijałkowskiego przez s. Marię Angelę Truszkowską ${ }^{4}$ i o. Honorata Koźmińskiego ${ }^{5}$. Stało się ono pierwszym honorackim zgromadzeniem habitowym. W 1858 roku afiliowane do kapucynów, w 1874 roku uzyskało dekret pochwalny Stolicy Apostolskiej, zaś 1907 roku ostateczne zatwierdzenie. W 1860 roku odbyła się w Warszawie kapituła felicjanek, która wybrała matkę Angelę Truszkowską na przełożoną generalną. Na kapitułę przybył tajnie z Rzymu generał zakonu kapucynów, Mikołaj od św. Jana z Marignano Bacchi. On zauważył u niektórych sióstr dar modlitwy. Kazał więc je oddzielić, nadać im regułę św. Klary i nazwać kapucynkami św. Feliksa. Wtedy to powstał w zgromadzeniu odłam klauzurowy, którego intencją było wspieranie działań czynnych felicjanek modlitwą. Klauzurę zamknięto 17 września 1860 roku. Do tej grupy dołączyła się matka Angela Truszkowska, która na przełożoną sióstr czynnych naznaczyła Magdalenę Borowską

Zgromadzenie Sióstr Świętego Feliksa z Kantalicjo Trzeciego Zakonu Regularnego Świętego Franciszka Serafickiego to instytut zakonny na prawach papieskich, którego członkinie składają profesję publicznych ślubów czystości, ubó-

${ }^{4}$ Siostry Felicjanki wydają w Krakowie periodyk Matka Angela i jej dzieło. Jest to biuletyn o błogosławionej Marii Angeli Truszkowskiej, założycielce Zgromadzenia Sióstr Felicjanek.

5 Jego troska o Zgromadzenie Sióstr Felicjanek odzwierciedla się w wielu listach z lat 1856-1913. Szerzej o Florentynie Wacławie Janie Stefanie Koźmińskim (ojcu Honoracie): Z. Kratochwil, Ojciec Honorat Koźmiński kapucyn w klasztorze zakroczymskim (1864-1892), „Studia Płockie” 27 (1999), s. 181-191.

${ }^{6}$ [M.Ch. Jasińska], Historia Zgromadzenia SS. Felicjanek - na podstawie rękopisów, cz. 1, Milwaukee-Kraków 1929, s. 319. 
stwa i posłuszeństwa i podejmują ewangeliczny sposób życia we wspólnocie. Celem zgromadzenia jest współpraca z Chrystusem w duchowej odnowie świata ${ }^{7}$. Jako zgromadzenie apostolskie siostry felicjanki spełniają swoją misję w Kościele poprzez kontemplację i działalność apostolską ${ }^{8}$. Od samego początku siostry zajmowały się wychowywaniem dzieci, zwłaszcza $\mathrm{z}$ warstw najuboższych, a także opiekowały się chorymi i bezdomnymi. Felicjanki zajmują się przede wszystkim religijnym i moralnym wpływem na społeczeństwo, działalnością wychowawczo-oświatową, charytatywną, opiekuńczo-społeczną, a także działalnością misyjną. W Polsce prowadzą szkoły i przedszkola, domy dla chorych kobiet i dla chorych dzieci, ośrodek socjoterapeutyczny, kuchnie dla studentów i jadłodajnie dla bezdomnych, zajmują się działalnością katechetyczną i misyjną. Zakon jest obecny na terenie Polski, USA, Kanady, Brazylii,

7 Szczegółowe prawa i obowiązki zawarto w konstytucjach. Por. Konstytucje Sióstr ś. Feliksa Trzeciego Zakonu św. o. Franciszka, Kraków 1907; Konstytucje Zgromadzenia Sióstr św. Feliksa (Siostry Felicjanki) oparte na Regule III Zakonu Regularnego św. Franciszka Serafickiego i na rozporzadzeniach kapituł generalnych z 1968 i 1970 roku, Rzym 1971.

${ }^{8}$ Główną misją zgromadzenia jest służba ludziom poprzez ewangelizację, pracę oświatową, wychowawczą oraz opieka nad ludźmi cierpiącymi i potrzebującymi pomocy. W Polsce to: katechizacja, grupy modlitewne, domy opieki dla ludzi starszych, dla dzieci niepełnosprawnych, szkoła podstawowa i gimnazjum, świetlice socjoterapeutyczne, przedszkola, jadłodajnie dla ubogich, ośrodek szkoleniowo-wychowawczy dla dzieci z niedokształconą mową, ośrodek pedagogiczno-rehabilitacyjny, praca w zakrystii, kancelarii, pomoc chorym i samotnym w ich mieszkaniach. Zgodnie z duchem założycielki siostry są gotowe na każde poświęcenie, by służyć tam, gdziekolwiek Bóg postawi i zawsze w taki sposób, jaki wskaże im. Por. R. Gołębiowski, Zgromadzenie sióstr Felicjanek (1), „Tygodnik Katolicki Niedziela” [edycja szczecińska] 37 (2008). 
Włoch, Wielkiej Brytanii, Francji, Kenii, Ukrainy, Estonii i Rosji. W Polsce istnieją trzy prowincje sióstr felicjanek: warszawska, krakowska i przemyska ${ }^{9}$.

\section{Przybycie Felicjanek do Galicji}

W latach 60. XIX wieku cesarz Austrii zgodził się przyjąć felicjanki w Galicji. Wówczas s. M. Angela Truszkowska listownie zachęcała je do wyjazdu do Krakowa. Felicjanki pochodzące z zaboru austriackiego udały się do tego jedynego krakowskiego domu poza granicami państwa rosyjskiego. Utrzymywał z nimi kontakt założyciel o. Honorat Koźmiński ${ }^{10}$. Dzięki staraniom i pośrednictwu bpa Antoniego Gałeckiego ${ }^{11}$ felicjanki uzyskały w 1865 roku pozwo-

${ }^{9}$ Początkowe dzieje sióstr felicjanek w Polsce opisuje o. Florian [Janocha], Felicjanki na jubileusz 50-letni ich działalności od roku 1855 do 1905, Kraków 1905.

${ }^{10}$ Por. B. Czaplicki, Mniszki Klaryski Kapucynki na ziemiach polskich w latach 1860-1945, „Śląskie Studia Historyczno-Teologiczne” 38 (2005), z. 1, s. 173-197.

${ }^{11}$ Antoni Junosza Gałecki (ur. 25 maja 1811 r. w Radłowie, zm. 10 marca 1885 r. w Wiedniu) - polski biskup rzymskokatolicki, administrator diecezji krakowskiej od $1862 \mathrm{r}$. Studiował w Wiedniu i Rzymie, gdzie uzyskał tytuł doktora teologii. W 1834 r. otrzymał święcenia kapłańskie. Piastował godność kanonika tarnowskiego, od 1853 r. pełnił funkcję dziekana kapituły tarnowskiej. Był wykładowcą w Seminarium Duchownym w Tarnowie. Wskutek działań władz austriackich 25 września 1862 r. mianowany został przez papieża Piusa IX biskupem tytularnym i wikariuszem apostolskim diecezji krakowskiej w zaborze austriackim. Przeciwnik powstania styczniowego, lojalny wobec władz zaborczych popadał w konflikty z wiernymi i duchowieństwem. Dnia 10 grudnia 1863 r. nakazał usunięcie wszelkich emblematów wojennych i symboli narodowych z grobów powstańczych na cmentarzach krakowskich. 
lenie na osiedlenie się w Galicji, tj. w ówczesnym zaborze austriackim $^{12}$. W tymże czasie zgromadzenie posiadało już

Za taką postawę odznaczony 16 grudnia 1864 r. austriackim Orderem Żelaznej Korony II klasy. Dbał o dyscyplinę i wysoki poziom opieki duszpasterskiej, popierał zgromadzenia zakonne. Przyjął do diecezji wygnane z Wielkopolski karmelitanki bose, urszulanki, w 1873 r. pijarów. W dniu 8 grudnia 1869 r. uczestniczył w uroczystości otwarcia Soboru Watykańskiego I, wziął udział w trzech uroczystych sesjach soborowych i na terenie diecezji krakowskiej jako jeden z pierwszych biskupów publicznie ogłosił treść soborowych dokumentów. Mieszkał w klasztorze księży misjonarzy w Krakowie na Stradomiu, ponieważ zbyt wolno postępowały prace przy odbudowie pałacu biskupiego zniszczonego pożarem. Nie udało mu się nawiązać porozumienia z wpływowymi rodami arystokratycznymi Krakowa ani ze środowiskiem profesorskim i akademickim UJ. Od 1876 r. podejmowano próby zmierzające do odwołania biskupa z Krakowa zakończone sukcesem w kwietniu 1879 r. Po nominacji Albina Dunajewskiego na stanowisko biskupa krakowskiego papież Leon XIII zwolnił z obowiązków i odwołał z funkcji bpa Gałeckiego, który opuścił Kraków incognito po 26 kwietnia 1879 r. Wyjechał do Wiednia, gdzie zamieszkał i zmarł w 1885 r. Został pochowany na cmentarzu publicznym w Wiedniu. Szerzej: J. Urban, Diecezja krakowska w XIX wieku [w:] Kościót krakowski w Tysiq̨cleciu, Kraków 2000; S. Dobrzanowski, Biskup Antoni Gałecki - wikariusz apostolski krakowski, [w:] Studia z historii Kościoła w Polsce, t. 1, red. E.H. Wyczawski OFM, Warszawa 1972, s. 5-96.

12 Granice między zaborami do 1815 r. ulegały zmianom. Po rozbiorach ziemie wschodnie Rzeczypospolitej (do Niemna) zostały wcielone do Rosji. Ziemie Polski centralnej (z Warszawą i Poznaniem) do 1806 r. należały do Prus, w latach 1807-1815 stanowiły Księstwo Warszawskie, a od 1815 r. (bez Krakowa i Poznania) Królestwo Polskie (tzw. Kongresowe) połączone unią personalną z Rosją. Królestwo Polskie formalnie miało pewną odrębność, która jednak ograniczona została po powstaniu listopadowym, a zlikwidowana po powstaniu styczniowym. W Galicji bardziej skomplikowane losy dotyczyły jej części zachodniej (z Krakowem) niż wschodniej (ze Lwowem). Po 1815 r. część Galicji Zachodniej tworzyło tzw. Rzeczpospolitą Krakowską, którą w 1848 r. wcielono do Austrii i poddano germanizacji. Możliwości repolonizacji nastąpiły dopiero po autonomii Galicji w 1866 r. 
trzy domy w Krakowie, toteż, korzystając z pozwolenia, zjeżdżało coraz więcej sióstr do podwawelskiego grodu. Było to połączone z niewygodami i trudnościami, głównie z powodu formalności związanych z przesiedleniem, a trwającymi nieraz bardzo długo. Bywały wypadki, że niektóre siostry, nie mogąc doczekać się aktu przesiedlenia, używały fortelu, w kapitularzu zdejmowały habit i używały odzieży świeckiej tak długo, dopóki nie otrzymały przesiedlenia. Identycznie każda siostra przyjeżdżająca z Kongresówki do Krakowa, nawet gdy była już profeską, musiała występować na zewnątrz w charakterze osoby świeckiej, rzekomo starającej się o wstąpienie do tegoż zgromadzenia. Posyłała więc na policję odpowiednie podanie o przesiedlenie. Policja wtajemniczona była przez komisarza zgromadzenia, ks. Wawrzyńca Oprzędka, i nie robiła w tym względzie trudności. Siostry mające obywatelstwo austriackie udały się do Krakowa, gdzie dzięki bpowi Gałeckiemu uzyskały w 1865 roku od władz austriackich zezwolenie na budowę domu macierzystego i otwarcie nowicjatu. Reszta rozproszonych sióstr, podlegająca s. Borowskiej, sukcesywnie przemieszczała się na teren Galicji ${ }^{13}$. W 1866 roku przybyła z Łowicza do Krakowa przełożona generalna s. M. Angela (Zofia) Truszkowska w celu organizowania na nowo zgromadzenia. Powstały w tym czasie placówki m.in. we Lwowie (1865), dwie w Krakowie (1865 i 1866), Stanisławowie (1866), Bełzie (1867), Wieliczce (1868), Sokalu i Tarnowie (1869), dwie w Przemyślu (1870

${ }^{13}$ Por. B. Łoziński, Leksykon zakonów w Polsce, Warszawa 1998, s. 194-195; M.B. Dmowska, Rozwój istuletnia działalność Zgromadzenia Sióstr Felicjanek w Polsce, [w:] Sacrum Poloniae Millennium, t. 8-9, Rzym 1961; Siostry Świętego Feliksa (Felicjanki), [w:] Żeńskie zgromadzenia zakonne w Polsce w latach 1939-1947, t. 1, Lublin 1982. 
i 1897), Bochni (1871), Żółkwi (1873), Drohowyżu (1880), Czerniowcach na Bukowinie (1887), w których siostry prowadzily ochronki, sierocince, internaty, szkoły ludowe, szwalnie, dom opieki dla dorosłych, kuchnię studencką ${ }^{14}$, opiekowały się chorymi, także podczas epidemii cholery (1866 i 1873), prowadziły bractwa, katechumenat i tercjarstwo $^{15}$. W 1901 roku ukonstytuował się zarząd prowincji krakowskiej pod wezwaniem Niepokalanego Serca Maryi (w 1939 roku istniały 34 placówki), oddzielony od zarządu generalnego. Z liczącej w 1910 roku wspólnoty 403 sióstr w 46 domach powstała prowincja lwowska pod wezwaniem MB Częstochowskiej ze 157 siostrami i 17 domami (w 1939 roku liczyła 232 siostry w 25 domach) ${ }^{16}$.

\section{Domy sióstr felicjanek w prowincji krakowskiej po 1945 roku $^{17}$}

Po II wojnie światowej prowincja krakowska zgromadzenia sióstr felicjanek przedstawiała się następująco:

I. Kuria Generalna znajdowała się w Krakowie przy ul. Batorego 16. Przełożoną generalną była s. M. Symplicyta Nehring.

${ }^{14}$ Od 1872 r. datuje się początek opieki nad studentami, z czego powstało osobne dzieło zgromadzenia - Kuchnia Siostry Samueli dla ubogich studentów. Kuchnie takie powstawały przy klasztorach sióstr felicjanek.

15 Szerzej: Magnificat 1855-1955. Pamiętnik stulecia Zgromadzenia Sióstr św. Feliksa (Felicjanek), Buffalo 1955.

${ }^{16}$ Por. „Roczniki Zgromadzenia Sióstr Felicjanek” 1 (1910) - 7 (1939).

${ }^{17}$ Archiwum Diecezjalne w Tarnowie (dalej: ADT), zespół FelicjankiZgromadzenie Sióstr Św. Feliksa z Kontalicji (CSSF), t. 1, lata 19472000, sygn. ZŻ/1, Pismo przełożonej generalnej Sióstr Felicjanek S.M. Bronisławy do Kurii biskupiej w Tarnowie z 7 II 1947 r., l. OL.I-2/38/47. 


\section{Dom Macierzysty prowincji krakowskiej}

w Krakowie, przy ul. Smoleńsk 16, łącznie liczył sióstr profesek chórowych: 215, konwersek: 106, nowicjuszek: 22, postulantek: 12 .

III. Domy zakonne na terenie diecezji tarnowskiej przedstawiały się następująco:

1. Dom św. Teresy z Avila w Tarnowie przy ul. Focha 14 ${ }^{18}$. Przełożoną była s. M. Anastazja Pierzchała. Siostry prowadziły zakład wychowawczy, ochronkę, szwalnię. W domu przebywało 10-11 sióstr.

2. Dom im. św. Stanisława BM w Tarnowie na Grabówce, przy ul. Lwowskiej 52. Przełożoną była s. M. Sylweria Opiekun. Prowadziły ochronkę miejską. Było 5-7 sióstr.

3. Bochnia, ul. Sienkiewicza 1. Przełożoną była s. M. Gastolda Sałacka. Prowadziły Ochronkę miejską. Sióstr - 5.

4. Bochnia, ul. Kraszewskiego 16. Przełożoną była s. M. Ewangelista Kłapkówna. Siostry prowadziły internat, kuchnię ludową, kuchnię dla niemowląt, sprawowały opiekę nad chorymi w mieście, Caritas. Sióstr - 6 .

5. Nowy Sącz, ul. Długosza 53. Przełożoną była s. M. Julitta Twardawa. Prowadziły zakład wychowawczy, ochronkę, szwalnię. Sióstr - 9.

6. Gorlice. Przełożoną była s. M. Salomea Filipowska. Ochronka była własnością Komitetu Ochronek Małych Dzieci. Sióstr - 4 .

${ }^{18}$ Obecna ulica gen. Józefa Bema miała uprzednio inne nazwy: Ogrodowa, Polskiego Października, M. Thoreza, F. Focha. Szerzej: K. Moskal, Bema Józefa generała ulica, [w:] Encyklopedia Tarnowa, red. A. Niedojadło, Tarnów 2010, s. 46-47. 
7. Grybów. Przełożoną była s. M. Kantalicja Zagrodzka. Pracowały w ochronce miejskiej (dom magistracki). Sióstr - 4 .

Kuria biskupia w Tarnowie dysponowała więc pełnym wykazem domów i ich obsady w 1947 roku.

Tabela 1. Wykaz domów zgromadzenia ss. felicjanek diecezji tarnowskiej - stan na 15 stycznia $1957 \mathrm{r}$.

\section{Lp. Miejscowość Liczba Dzieła sióstr}
1. Rytro
4 1. Praca w parafii
2. Pracownia szat liturgicznych
2. Męcina
5 1. Przedszkole Caritas
2. Nauka religii dzieci szkolnych
3. Tarnów
11 1. Zakład wychowawczy Caritas
2. Katechezy dla dzieci przedszkolnych
3. Pracownia szat liturgicznych
4. Nowy Sącz
13 1. Zakład wychowawczy Caritas
2. Przedszkole
3. Katechezy dla dzieci przedszkolnych
5. Bochnia
3 1. Internat Caritas
2. Katechezy dla dzieci przedszkolnych
6. Grybów
$4 \quad$ 1. Praca przy parafii
2. Katechezy dla dzieci przedszkolnych
3. Szycie szat liturgicznych

Źródło: ADT, zespół Felicjanki-Zgromadzenie Sióstr Św. Feliksa z Kantalicjo (CSSF), t. 1, lata 1947-2000, sygn. ZŻ/1, Wykaz domów Zgromadzenia SS. Felicjanek diecezji tarnowskiej - stan na 15 stycznia 1957 r., L.p. 22/57, k. 1.

Jak więc widać, w diecezji tarnowskiej w 1957 roku było sześć domów sióstr felicjanek. Mieszkało i pracowało w nich 39 sióstr. Zajmowały się pracami na rzecz dzieci, katechizowały oraz szyły i odnawiały szaty liturgiczne. 


\begin{tabular}{|c|c|c|c|c|c|c|c|}
\hline & 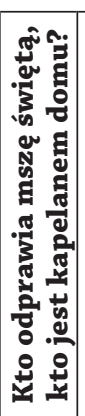 & 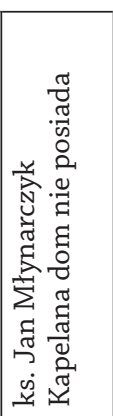 & 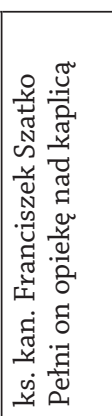 & 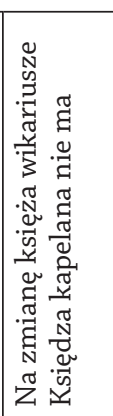 & 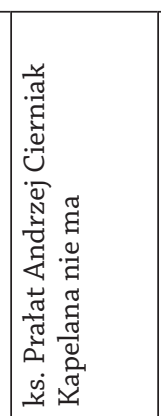 & 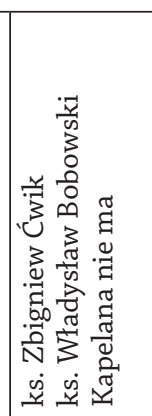 & 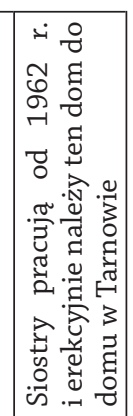 \\
\hline & 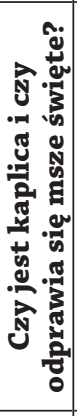 & 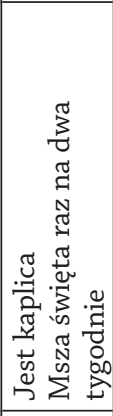 & 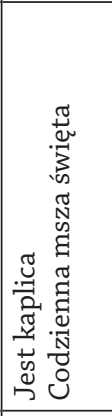 & 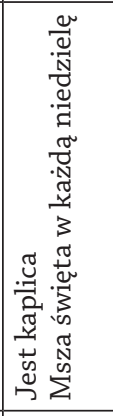 & 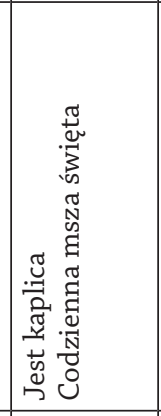 & 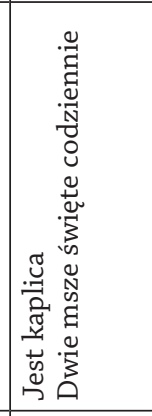 & 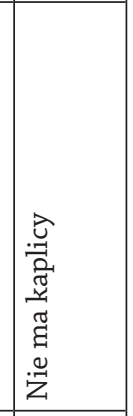 \\
\hline & 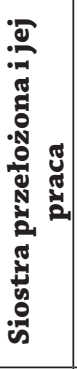 & 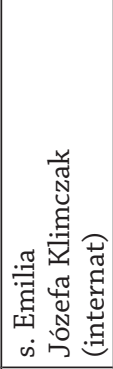 & 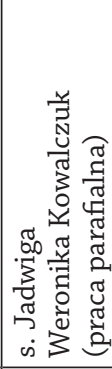 & 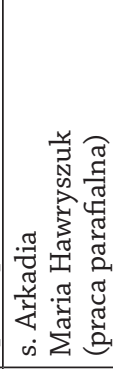 & 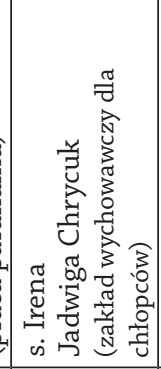 & 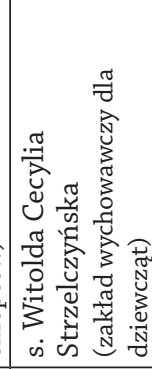 & 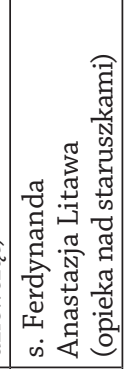 \\
\hline & 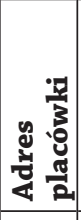 & 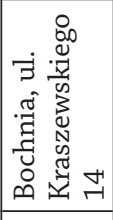 & 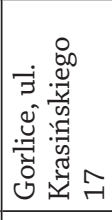 & 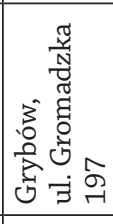 & 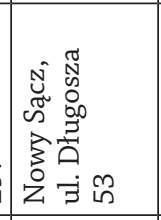 & 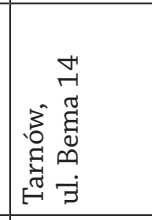 & 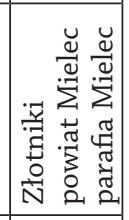 \\
\hline & $\dot{\Delta}$ & $\dot{r}$ & ג & $\dot{m}$ & मं & in & $0^{\circ}$ \\
\hline
\end{tabular}


Źródło: ADT, zespół Felicjanki-Zgromadzenie Sióstr Św. Feliksa z Kantalicji (CSSF), t. 1, lata 1947-2000, sygn. ZŻ/1, Wykaz domów w diecezji tarnowskiej, pismo Zgromadzenia SS. Felicjanek do Kurii biskupiej w Tarnowie z 5 XI 1962 r., L. dz. 148/62.

Z danych tabelarycznych wynika, że w 1962 roku w diecezji tarnowskiej było sześć domów sióstr felicjanek, w tym jeden nowo założony w Złotnikach, powiat mielecki, który erekcyjnie był przypisany do domu tarnowskiego. W pięciu domach były kaplice, w których odprawiano msze święte. Niestety domy nie miały swoich kapelanów.

\section{Domy i dzieła w Tarnowie}

Dom filialny w Tarnowie, czyli Dom św. Teresy z Avila (25 grudnia 1869 - 1992)

W 1861 roku, gdy siostry felicjanki na prośbę prezesowej Komitetu Ochrony w Krakowie objęły ochronkę św. Kajetana na Wesołej, księżna Izabela Sanguszkowa ${ }^{19}$, prze-

19 Izabela Maria Lubomirska z Lubomierza herbu „Drużyna” (ur. 1 marca 1808 r. w Przeworsku, zm. 18 marca 1890 r. w Gumniskach), księżna, żona Władysława, córka Henryka Lubomirskiego, ordynata przeworskiego. Wielkiej urody i pobożności, znana z działalności dobroczynnej. Dnia 6 lipca 1829 r. w Przeworsku wyszła za mąż za księcia Władysława Hieronima Sanguszko. Mieli pięcioro dzieci: Jadwigę Klementynę Sanguszko (1830-1918) - wyszła za mąż za księcia Adama Stanisława Sapiehę; Romana Damiana Sanguszko - 19 października 1868 r. ożenił się z hrabianką Karoliną von Thun und Hohenstein (18481916), prawnuczką hrabiego Alojza Fryderyka von Brühla; Pawła Romana Sanguszko - jego pierwszą żoną od 7 października 1862 r. była hrabianka Maria Gfn von der Borch-Warkland (1835-1868), a drugą od 1875 r. hrabianka Georgina Apponyi de Nagy-Appony (ur. 1841); Helenę Sanguszko i Eustachego Stanisława Sanguszko, który 23 lutego 1895 r. ożenił się 
łożona zakładu sierot żeńskich w Tarnowie, dowiedziawszy się o nowym zgromadzeniu, usilnie prosiła s. M. Augustynę, ówczesną przełożoną w Krakowie, aby felicjanki objęły jej zakład tarnowski. Ksiądz dr Wawrzyniec Gwiazdoń20, ówczesny proboszcz parafii katedralnej i sekretarz Towarzystwa Dobroczynności w Tarnowie, w imieniu księż-

z hrabianką Konstancją Anną z Zamoyskich (1864-1941). Była ona założycielką i pierwszą przewodniczącą Towarzystwa Dobroczynności w Tarnowie, wielką filantropką.

${ }^{20}$ Wawrzyniec Gwiazdoń - pierwotne nazwisko: Gwiazdonik (ur. 13 maja 1822 r. w Jordanowie, zm. 23 listopada 1885 r. w Tarnowie), syn Michała Gwiazdonika i Marianny z d. Bala, brat Błażeja i bratanek Wojciecha. Szkołę podstawową i średnią ukończył w Podolińcu. Studia teologiczne odbył w Tarnowiei od 1841 r. kontynuował w Wiedniu. Święcenia kapłańskie otrzymał 13 sierpnia 1845 r. z rąk bpa J.G. Wojtarowicza. Od 22 października 1845 r. był wikariuszem w Rychwałdzie, skąd pod koniec 1846 r. został skierowany na dalsze studia teologiczne do Wiednia, gdzie 23 lipca 1850 r. uzyskał doktorat z teologii na tamtejszym uniwersytecie. Po powrocie do diecezji został profesorem historii Kościoła w Tarnowskim Seminarium Duchownym. Dnia 20 stycznia 1866 r. został kanonikiem gremialnym kapituły katedralnej w Tarnowie, w 1880 r. prepozytem infułatem tejże kapituły. W latach 1879-1881 pełnił obowiązki proboszcza parafii katedralnej w Tarnowie. W 1863 r. otrzymał godność szambelana papieskiego, a w 1865 r. prałata honorowego ojca świętego. W dwa dni po śmierci bpa Pukalskiego, 8 stycznia 1885 r. kapituła wybrała go wikariuszem kapitulnym. Cieszył się uznaniem duchowieństwa i świeckich. Zmarł 23 listopada 1885 r. w Tarnowie i spoczął w podziemiach kaplicy św. Józefa na Starym Cmentarzu. Por. P. Gajda, Sylwetki biograficzne profesorów Seminarium Duchownego w Tarnowie, „Currrenda” (1959), nr 109, s. 298-300, 309-310; P. Gajda, Gwiazdoń Wawrzyniec (1822-1885), [w:] Słownik polskich kanonistów, cz. 1, s. 164-165; B. Kumor, Diecezja tarnowska, Kraków 1985, s. 319-321; M. Leśniak, X. dr Wawrzyniec Gwiazdoń, "Currenda” (1885), s. 161; A. Petrani, Nauka prawa kanonicznego w Polsce w XVIII i XIX wieku, Lublin 1961, s. 88; M. Sopata, Wykaz wikariuszy generalnych, oficjałów i kanclerzy $w$ diecezji tarnowskiej, „Currenda” (1968), nr 118, s. 160. 
nej Sanguszkowej kilkakrotnie pisał do o. Koźmińskiego, fundatora, w tej sprawie i otrzymał od niego przyrzeczenie przysłania sióstr do Tarnowa. Tymczasem czas mijał, a obietnicy z niewiadomej przyczyny nie dotrzymywano. Nadeszły lata 1863 i 1864 - powstanie, kasata zgromadzenia, rozproszenie. Dopiero 25 listopada 1869 roku s. M. Anna, jako przełożona generalna, wysłała do Tarnowa pierwsze felicjanki: s. M. Symplicję Gradowską jako ancillę, s. M. Joannę Charzewską do gospodarstwa i ogrodu i s. M. Nepomucenę Jałoszyńską do robót i prowadzenia zakładu. Jak wynika ze źródłowych materiałów archiwalnych, siostry felicjanki ostatecznie objęły dom przy obecnej ul. Bema $^{21} \mathrm{nr} 14 \mathrm{w} 1892$ roku $^{22}$. Od stycznia do sierpnia 1870 roku obowiązki przełożonej domu pełniła s. M. Augustyna Bielawska ${ }^{23}$.

W dniu 1 września 1843 roku Tarnowskie Towarzystwo Dobroczynności otworzyło dla 10 sierot zakład w wynajętym domku Popławskiego w Tarnowie, w pobliżu kościoła NMP „na Burku”, i oddało go pod opiekę osób świeckich ${ }^{24}$. Od 1 października 1844 roku zakład sierot został przeniesiony do dworku p. Gadzińskiego na Strusinie, przy ul. Chyszowskiej, który księżna Sanguszkowa kupiła za własne

${ }^{21}$ Zob. M.P. Lenart CSSF, Prowincja krakowska Niepokalanego Serca Najświętszej Maryi Panny Zgromadzenia Sióstr Felicjanek. Leksykon domów, t. 2 (1861-1981), cz. 5, Kraków 2004, s. 52.

${ }^{22}$ ADT, zespół Felicjanki-Zgromadzenie Sióstr Św. Feliksa z Kontalicji (CSSF), t. 1, lata 1947-2000, sygn. ZŻ/1, Sprawozdanie z wizytacji kanonicznej sióstr Felicjanek z Domu św. Teresy w Tarnowie, ul. Bema 14 przeprowadzonej w dniach 10-12 VI 1974 r. przez ks. Z. Ćwika, k. 1.

${ }^{23}$ Zob. M.P. Lenart CSSF, Prowincja krakowska..., dz. cyt., s. 74.

${ }^{24}$ APSFK, Księga posiedzeń Towarzystwa Dobroczynności od 1843 r., b. sygn., s. 1-4. 
fundusze na cele zakładu ${ }^{25}$. Wychowywano tam mniej więcej 40 sierot. Fundusz żelazny na utrzymanie zakładu wynosił 20 tys. złp. Miejscowe Towarzystwo Pań Dobroczynności pamiętało o sierotach, zbierało na nie składki, urządzało przedstawienia i w ten sposób zebranymi funduszami zasilało kasę zakładową. Dzieci uczyły się robót kobiecych, szycia i haftów, które to roboty pokrywały w znacznej części wydatki domowe. Pobierały naukę, ale tylko w zakresie szkoły elementarnej. Nauki religii udzielał miejscowy ksiądz katecheta. Mniej zdolne do robót uczennice kierowały się na służące pokojowe, kucharki i praczki. Oto, co napisano w tarnowskiej gazecie „Pogoń”:

Wychowaniem sierót, nauk w przedmiotach szkolnych i robotach żeńskich, zajmują się chlubnie znane w całym naszym kraju Siostry Felicyanki, nauki religii udziela ks. kan. dr. Alojzy Góralik, kasę prowadzi p Świerczyński, kasyer ks. Sanguszki. Obecnie znajduje się w zakładzie 5 dziewcząt, nie wszystkie jednak są na funduszu Towarzystwa. Połowa jest takich, za które płacą osobno ich opiekunowie, albo nawet rodzice. Jeżeli zakład daje ubranie, płaci się miesięcznie za całe utrzymanie, wychowanie i naukę 9 złr., jeżeli ubranie jest $\mathrm{z}$ domu, natenczas tylko 7 złr. Zakład tarnowski wiele już wychował sierót, a daje im odpowiednie do ich przyszłego stanu wykształcenie, daje silny grunt religijno-moralny, nie tylko zabezpieczył je przed nieuchronną zgubą, ale zapewnił utrzymanie z poczciwej pracy na całą przyszłość. Zakład taki zasługuje tedy na szersze zainteresowanie się niem przez nasze społeczeństwo ${ }^{26}$.

\footnotetext{
${ }^{25}$ Zob. M.P. Lenart CSSF, Prowincja krakowska..., dz. cyt., s. 54.

${ }^{26}$ Tarnowski zakład sierót, „Pogoń. Dwutygodnik Ekonomiczno-Społeczny" 4 (1884), nr 10, s. 4.
} 
Siostrom przeznaczono oprócz pełnego utrzymania rocznie 200 złp. Dom był urządzony ubogo i wielu rzeczach brakowało. Sióstr jednak to nie zrażało. Przybywszy na miejsce, zaraz objęły zakład i urządziły go według trybu zakonnego. Bardzo uroczyście odbyło się poświęcenie domu, w którym wzięło udział mnóstwo ludzi. Jak więc widać, siostry w Tarnowie zostały bardzo dobrze przyjęte. Kaplicy na razie urządzić nie mogły z powodu braku potrzebnych sprzętów i aparatów, więc chodziły jakiś czas do kościoła. W chwili, gdy siostry objęły zakład, było w nim tylko 25 dziewczynek, w tym 12 sierot, utrzymywanych przez księżnę; niektóre były płatne, parę utrzymywały panie komitetowe, były też i zupełnie bezpłatne. Siostra M. Nepomucena z właściwą sobie gorliwością i poświęceniem zabrała się do pracy nad wychowaniem dzieci. Pomocy nie miała żadnej, tylko na ćwiczenia zmieniała ją siostra, aby dzieci nigdy same nie zostawały. Siostra M. Symplicja zajęła się zarządem domu i nauką dzieci, a s. M. Joanna kuchnią, ogrodem i gospodarstwem. W kilka miesięcy potem s. M. Joanna zachorowała na tyfus i wkrótce zmarła. Matka generalna przybyła $z$ socjuszkąa ${ }^{27}$ na wieść o ciężkiej chorobie siostry, nie odstępowała jej do ostatniej chwili i pozostała na pogrzebie, który odbył się przy udziale licznie zebranych kapłanów i osób świeckich. Siostry poniosły w niej wielką stratę, była im bowiem nie tylko wielką pomocą, ale i przykładem.

W 1871 roku przeznaczono na ancillę s. M. Augustynę, która z właściwą sobie energią wzięła się do urządzenia

${ }^{27}$ Socjuszka to asystentka wspierająca przełożoną w zakonie. Nie posiada formalnej władzy nad powierzonymi sobie sprawami, ułatwia natomiast komunikację pomiędzy przełożoną a zakonnicami. 
domu i szkoły dla „przychodnich” dziewcząt. Dziewczęta bardzo licznie zaczęły się schodzić, słuchały nauk wykładanych przez księdza katechetę i przez siostry. Liczba uczennic przekraczała wtedy setkę. Gdy praca sióstr w zakładzie nabrała już dużego rozpędu, zaczęły myśleć o kaplicy. Duchowieństwo miejscowe, ofiarne i życzliwe, bardzo im w tym dopomagało. Urząazziły ołtarz z tabernakulum i sprawiły, co najkonieczniejsze, aby msza święta mogła się tam odprawiać. Biskup Pukalski chętnie udzielił pozwolenia na Sanctissimum i mszę świętą. Odtąd kapłani codziennie przychodzili z mszą, a siostry odprawiały wszystkie swoje ćwiczenia również w kaplicy, zmieniając się tak, aby dzieci zakładowe i przychodnie zostawały zawsze pod opieką i okiem sióstr. Siostra M. Augustyna zajęła się nadto świeckimi tercjarkami, miewając dla nich nauki na zebraniach miesięcznych i zachęcając do pobożnego życia. Zapoczątkowała również żywy różaniec, do którego zapisywało się wiele osób.

W 1871 roku wybuchła w Tarnowie i okolicy ponownie cholera, pochłaniając mnóstwo ofiar ${ }^{28}$. Dla sióstr felicjanek otworzyło się obszerne pole do heroicznego poświęcenia. Przez sześć tygodni pielęgnowały chorych w szpitalu cholerycznym. Na szczęście żadna z nich nie zachorowała. Wielkim poświęceniem dla chorych odznaczały się w tym czasie m. M. Augustyna, s. M. Kandyda, s. M. Serafina i s. M. Wacława. Na kongregacji zakonnej w 1872 roku przeznaczono na ancillę do Tarnowa s. M. Rafaelę, bardzo gorliwą

${ }^{28}$ Wcześniej notowana od 1866 r. Zob. J. Starkel, O cholerze nagminnej $w$ mieście obwodowem Tarnowie $w$ jesieni 1866 roku. Sprawozdanie urzędowe, „Przegląd Lekarski” 6 (1867), nr 5, s. 33-35; nr 6, s. 41-43. 
zakonnicę, która nadto odznaczała się wielkim nabożeństwem do Najświętszego Sakramentu.

W 1873 roku założono ochronkę dla małych dzieci, w wieku od 3 do 6 roku życia, potrzebną w tym mieście. Umieszczono ją w osobnej oficynie, w której dawniej ulokowana była pralnia, a ponieważ sala przeznaczona na ochronkę była dość mała, siostry postarały się o postawienie werandy, aby dzieci miały więcej świeżego powietrza. Mieszkańcy Tarnowa, a zwłaszcza najbiedniejsi wyrobnicy, przyjęli tę wiadomość $z$ wielką radością, gdyż matki, idąc na zarobek, mogły bezpiecznie pozostawiać swoje dzieci pod opieką sióstr, które uczyły je pacierza i katechizmu, śpiewały i bawily się z nimi, a najbiedniejszym dawały obiad.

W tymże 1873 roku jedno z nowo powstałych pism galicyjskich, „Wiadomości Kościelne”, wydawane we Lwowie, umieściło następującą korespondencję z Tarnowa:

Dzięki troskliwym o chwałę Bożą i wzrost moralności zabiegom dostojnej rodziny Sanguszków mamy w Tarnowie Felicjanki. Na przedmieściu, zwanym Strusina, tuż przy gościńcu stoi mały domek z bardzo małym ogródkiem. Umieszczony napis: „Ochronka sierot” wskazuje przechodniowi, kto mieszkańcem tego domu: Sieroty (?) o nie, odkąd Felicjanki w Tarnowie, sieroty nie wiedzą nawet, co znaczy imię, które noszą. Felicjanki są ich matkami, tyle droższymi, o ile pielęgnując ciało, a zarazem kształcąc duszę, przewyższają niejedną z matek, zbyt troskliwych o dobro doczesne, z zaniedbaniem dobra prawdziwego, duchownego, wiecznego. Przeszło 120 dziewcząt ze Strusiny, a nawet z najdalszych części miasta, gromadzi się w szkole, której Felicjanka jest duszą. Tu uczą się czytać, pisać i rachować, tu usłyszysz odpowiedzi z historii polskiej, jakich 
byś daremnie szukał pomiędzy gimnazistami. Tu dziewczątka zajęte są robótkami ręcznymi, które otrzymały pierwszeństwo na tarnowskiej wystawie rolniczo-przemysłowej. Oprócz szkoły Felicjanki nasze, za staraniem istniejącego tu Towarzystwa św. Wincentego a Paulo, przyjęły na siebie ciężar utrzymywania Ochronki. W osobnej, na ten cel umyślnie przyrządzonej sali, przeszło 50 dzieci od 3-5 lat cały dzień pod dozorem Felicjanki otrzymuje schronienie, zabawę i naukę odpowiednią. Ileż przez to zyskują te biedne dzieciaki, ileż zyskują rodzice, ile miasto nasze! Lecz Felicjanki na tym nie poprzestają. Zwracają one baczną uwagę na dorastające dziewczęta, a, widząc grożące im niebezpieczeństwo, tulą je do siebie, jak najtroskliwsze matki. Co niedzielę i święto, ba, nawet co dzień widzieć można u Felicjanek panienki z pierwszych domów miasta naszego; ta z książką, owa z robótką, tamta po radę spieszy, a każda z wdzięcznością o Mateczkach mówi i z uwielbieniem. Felicjanki nasze są promotorkami Różańca żywego. W każdą 1-szą niedzielę miesiąca na ogólnym zgromadzeniu Felicjanka przewodniczy. Uczy katechizmu, prostuje złe obyczaje, gromi i upomina daleko nieraz skuteczniej, aniżeli kapłan, bo posiada sekret trafiania do serc i przekonania kobiety! A cóż dopiero powiedzieć o Felicjankach naszych w szpitalu miejskim w czasie epidemii, która codziennie 30, a nawet 40 ofiar pochłaniała? Z ust ludzi, którzy nie grzeszą pobożnością, można było słyszeć: „Prawdziwe to Anioły, z nieba nam Bóg je zesłał, bez ich pomocy nie dalibyśmy sobie rady". I rzeczywiście wyobrażenie ludzkie przechodzi, do jakiego stopnia posunęło się poświęcenie Felicjanek w tutejszym szpitalu. Tam, gdzie najbliżsi krewni, ojciec i matka, zajrzeć nie chcieli, widziałeś Felicjankę, jak gdyby królową świata. To też szacunek 
dla Felicjanek w mieście naszym - wielki, a wdzięczność nigdy nie wygaśnie. Bogu zaś, który w Kościele Swoim, między służebnicami Swymi, ducha apostolskiego utrzymuje, niech będzie chwała i dziękczynienie! ${ }^{29}$.

Powyższy opis maluje usposobienie iducha, jakim owiane były ówczesne siostry, niecofające się przed żadną pracą, gdy chodziło o chwałę Bożą i zbawienie dusz. Liczne prace nie przeszkadzały bynajmniej w zachowaniu wzorowej obserwacji, a miłość wzajemna ułatwiała wszelki trud. Ponieważ ubóstwo w zakładzie było wielkie, siostry otrzymały pozwolenie na kwestę w okolicy. Odbywały ją zwykle jesienną porą. Domy okoliczne z radością witały siostrykwestarki i za szczęście sobie miały, gdy siostry próg ich przekroczyły. Siostra M. Rafaela, zdając sprawę ojcu fundatorowi z czasów swojego przełożeństwa w Tarnowie, pisała między innymi:

Objęłam zarząd domu św. Teresy w Tarnowie na początku września 1872 r., a w ciągu tego czasu nie przestaję uwielbiać cudów łaski, opieki, miłosierdzia i miłości Boskiej nad nami. Utrzymanie bowiem domu bardzo szczupłe - $200 \mathrm{H}$. rocznie przeznaczają dla sióstr - jest nas 5 , na dziecko zaś dają nam 72 fl. rocznie. Przy teraźniejszej drożyźnie ludzkim rozumem pojąć trudno, że tak szczupłe utrzymanie wystarcza - i to nie tylko dla nas, ale dla wszystkich ubogich, zgłaszających się do ochronki, a tych jest bardzo dużo - i dla Pana naszego, w Przenajświętszym Sakramencie utajonego, bo kapliczka uboga nie ma żadnych dochodów stałych. Nigdy nam jednakże nie zabrakło pieniędzy

${ }^{29}$ Korespondencye, Felicyanki (Koresp. z Tarnowa), „Wiadomości Kościelne" 1 (1873), nr 1, s. 6-7. 
na światło w pierwszą niedzielę miesiąca, kiedy Pan wychodzi z ukrycia Swego i przez dzień cały króluje w małej kapliczce, zapewniając i przypominając, że „jednego potrzeba", a gdy Jego mamy, wszystko inne otrzymujemy w dodatku. I tak napełnia Pan pokojem sługi Swoje i miłości świętej uczy i dobrze nam jest w tym domku ubogim, gdzie Pan Sam Królem, a Najświętsza Matka Jego - Panią i Królową, a św. Opiekun i naszym Opiekunem i Gospodarzem i Prokuratorem i Lekarzem. Oprócz sierot i dzieci, przyjętych na wychowanie do Zakładu tutejszego, których jest wr. b. 25 - mamy jeszcze szkołę dziewcząt przychodnich, których liczba przechodzi setką. Nadto 50 maleńkich dziatek w ochronce, otwartej w roku zeszłym, na początku kwietnia. Tę całą pracę wziął Pan wyraźnie na siebie, bo pomimo małej liczby Sióstr i słabych sił naszych - więcej pociechy, niż biedy mamy z tych dzieci, tak z przychodnich, jak i z domowych, pomimo że ludność tutejsza w ogóle nie jest dobrze usposobiona. Garną się jednak ludzie do małej kapliczki naszej i coraz liczniej się zbierają, bo ich do Pana Utajonego prowadzi Królowa Najśw. Serca Jego. Nabożeństwo do Serca Jezusowego i do Królowej tego Serca bardzo się szerzy pomiędzy ludem okolicznym i błogie owoce wydaje. Mamy także i Żywy Różaniec i Apostolstwo Modlitwy i świeckie tercjarki, a kapłani tutejsi tak są łaskawie usposobieni dla Zgromadzenia naszego, że nie tylko nie przeszkadzają, ale pomocą kapłańską bardzo dzielnie nas wspierają tak w rozszerzaniu stowarzyszeń, jak i w pracy około dzieci nam powierzonych ${ }^{30}$.

${ }^{30}$ [M.Ch. Jasińska], Historja Zgromadzenia SS. Felicjanek na podstawie rękopisów, cz. 2, Kraków 1929, s. 168. 
W 1877 roku przybyły z Gniezna do Tarnowa, by się tu osiedlić siostry urszulanki ${ }^{31}$, skasowane przez rząd pruski. Założyły przy ulicy Ogrodowej konwikt i szkołę ludową, do której były obowiązane uczęszczać miejscowe dzieci, uczące się dotąd w szkółce felicjanek. Dziatwa, przywiązawszy się do sióstr felicjanek, z wielkim żalem rozstawała się ze swymi "mateczkami”, jak powszechnie nazywano felicjanki, i niemal codziennie przybiegała do ochronki, by się choć trochę nimi nacieszyć.

W 1880 roku ancillą została s. M. Sancja i była nią przez sześć lat. Siostra ta zajmowała się gorliwie rozszerzaniem wszelkich bractw. $Z$ jej inicjatywy zawiązało się w Tarnowie Stowarzyszenie Pań św. Wincentego a Paulo ${ }^{32}$, których głównym zadaniem było zajmowanie się ubogimi. Dyrektorem

${ }^{31}$ Siostry Urszulanki UR to zakon międzynarodowy urszulanek, powstały z Towarzystwa św. Urszuli. Początki wiążą się z 1535 r. Oprócz trzech ślubów (czystości, ubóstwa i posłuszeństwa) składają czwarty nauczania dziewcząt. W 1900 r. powstały urszulanki Unii Rzymskiej. Do Polski zakon urszulanek przybył w 1857 r. na prośbę abpa gnieźnieńskiego L. Przyłuskiego i osiedlił się w Poznaniu. Jednak wskutek Kulturkampfu w 1875 r. z Poznania urszulanki przeniosły się do Tarnowa. W 1919 r. zawiązały unię polską i powróciły do Poznania. Pozostał czynny dom w Tarnowie. Szerzej: U. Borkowska, Urszulanki, [w:] Encyklopedia katolicka, t. 19, red. E. Gigilewicz, Lublin 2013, kol. 1406-1408.

${ }^{32} \mathrm{~W} 1843$ r. powstało w Tarnowie Towarzystwo Dam Dobroczynności, którego założycielką była księżna Izabela z Zamoyskich Sanguszkowa. Przyjęło ono statut wincentyński. $\mathrm{Na}$ jej wniosek sprowadzono do Tarnowa zgromadzenie sióstr felicjanek, które ściśle współpracowało ze stowarzyszeniem wincentyńskim. Pierwszą placówkę Stowarzyszenia Pań Miłosierdzia zorganizowano w Tarnowie w 1872 r. przy jedynej wówczas parafii. Zostało ono 10 października 1872 r. agregowane do Rady Głównej w Paryżu. Szerzej: Stowarzyszenie Pań Miłosierdzia Św. Wincentego á Paulo, [w:] Księga Pamiątkowa trzechsetlecia Zgromadzenia Księży Misjonarzy 1625-1925, Kraków 1925. 
stowarzyszenia został ks. infułat Stanisław Walczyński, który co miesiąc miewał nauki do pań, a s. M. Sancja kierowała towarzystwem. Wskazywała biednych i chorych, których panie odwiedzały, a sama zanosiła najbiedniejszym bony na prowianty, które dostarczało towarzystwo. Stowarzyszenie Pań św. Wincentego a Paulo w Tarnowie przyczyniło się również do utrzymania ochronki ${ }^{33}$.

W 1883 roku spokojne życie sióstr zmącone zostało burzą ze strony zarządu zakładu. Księżna Izabela Sanguszkowa nosiła się od dawna z zamiarem stworzenia zakładu dla podrzutków, lecz co najgorsze, zrobić to chciała przez skasowanie zakładu sierot. Przedstawiła w Krakowie swój zamiar matce generalnej, która naturalnie żadnej opozycji w tym nie czyniła, będąc gotową zaraz siostry zabrać, skoro tylko sieroty porozmieszczają; jedne miały być zwrócone rodzinom, inne odesłane do obowiązków. Duchowieństwo jednak tarnowskie, dowiedziawszy się o projekcie księżnej, oparło się temu bardzo silnie. Wobec tego księżna zostawiła sprawę na razie w zawieszeniu, tym bardziej że i panie komitetowe, które zbieraniem składek starały się o pomnożenie funduszu żelaznego, były temu przeciwne. Siostry tymczasem wraz z dziećmi zanosiły gorące modły do Matki Bożej Nieustającej Pomocy i opiekuna swego, św. Józefa, o oddalenie nieszczęścia. Bóg ufność sług swych nagrodził. Po dłuższym namyśle postanowili księstwo zakład zostawić, a nadto, chcąc go uczynić wiekopomną pamiątką swej dobroczynności, stworzyli stały fundusz, z którego procentów dom ten miał czerpać środki na utrzymanie.

${ }^{33}$ [M.Ch. Jasińska], Historja Zgromadzenia, cz. 2, dz. cyt., s. 171. 
W 1885 roku zmarła księżna Izabela Sanguszkowa i opiekunką zakładu została księżniczka Helena. Siostra Sancja wciągnęła ją do Towarzystwa św. Wincentego, zapoznając ją z nędzą ubogiej klasy wyrobniczej, o której księżniczka nie miała pojęcia. Zaczęła działać, odwiedzając, według wskazówek s. Sancji, ubogich i chorych i wspierając ich jałmużną. Dziękowała siostrze, że ją nauczyła przychodzić z pomocą nieszczęśliwym, i żałowała, że wcześniej nie poznała się z uczynkami miłosierdzia. Niestety księżniczka Helena $^{34}$ niedługo żyła.

Po sześciu latach pracy w Tarnowie s. M. Sancja wyjechała do USA, a ancillą w tarnowskim domu została s. M. Michalina Łabędzka, która urząd ten pełniła przez trzy lata. Siostra M. Sancja, powróciwszy w 1888 roku z Ameryki, objęła na nowo zarząd zakładu tarnowskiego ${ }^{35}$.

Na prośbę sióstr i sekretarza Towarzystwa 17 listopada 1893 roku książę Roman Damian Sanguszko kupił „dla Sióstr i Zakładu własny domek” od Józefy Tokarzowej za 23 tys. złr. w.a. Była to murowana piętrowa kamienica z dużym ogrodem w Tarnowie na Strusinie nr 281, przy ul. Ogrodowej ${ }^{36}$.

${ }^{34}$ Helena Sanguszko (ur. 1836 r., zm. 15 maja 1946 r. w Tarnowie), księżniczka, córka Władysława i Izabeli z Lubomirskich. Działała charytatywnie, pochowana w kaplicy rodowej na Starym Cmentarzu w Tarnowie. Por. E. Danowska, Sanguszkówna Helena, [w:] Encyklopedia Tarnowa, dz. cyt., s. 389.

${ }^{35}$ E. Danowska, Sanguszkówna Helena, dz. cyt., s. 172.

${ }^{36}$ Obecnie jest to ul. gen. J. Bema. 
Tabela 3. Wykaz sióstr przełożonych Domu zgromadzenia ss. felicjanek pw. św. Teresy z Avila w Tarnowie w latach 1869-1983

\section{Ip. Imię zakonne i nazwisko siostry przełożonej}

1. s. M. Symplicja Gradowska

2. s. M. Augustyna Bielawska p.o.

3. s. M. Paula Czyżewska

4. s. M. Augustyna Bielawska

5. s. M. Rafaela Sadowska

6. s. M. Stanisława Graybner

7. s. M. Modesta Pstrokońska

8. s. M. Augustyna Bielawska

9.

10. s. M. Beatriks Schnage

\begin{tabular}{lll}
\hline 11. & s. M. Michalina Eabęcka & 188 \\
\hline 12. & s. M. Sancja Patek
\end{tabular}

13. s. M. Klementyna Kabat

14. s. M. Sancja Patek

$15 . \quad$ s. M. Modesta Prokopowicz p.o.

16. s. M. Leona Wojtuszko

17. s. M. Rajmunda Kruszyńska

18. s. M. Karolina Dul

19. s. M. Prudencja Kobylińska

20. s. M. Anastazja Pierzchała

21. s. M. Prudencja Kobylińska

22. s. M. Dioniza Borowska

23. s. M. Klara Kotowska

24. s. M. Karolina Dul

25. s. M. Ksawera Wesoły

26. s. M. Anastazja Pierzchała

27. s. M. Sylweria Opiekun

28. s. M. Zbigniewa Smoleń

29. s. M. Ewangelista Kłap

30. s. M. Witolda Strzelczyńska
Czas sprawowania urzędu przełożonej

1869-1870

1870

1870-1871

1871-1872

1872-1875

1875-1876

1876-1877

1877-1880

1880-1885

$1885-1886$

1886-1888

1888-1895

1895-1896

1896-1901

1901-1902

1902-1909

1909-1915

1915-1918

1918-1921

1921-1926

1926-1929

1929-1932

1932-1938

1938-1939

1939-1945

1945-1951

1951-1954

1954-1957

1957-1959

1959-1963 


\begin{tabular}{lll}
\hline 31. & s. M. Zbigniewa Smoleń & $1963-1969$ \\
\hline 32. & s. M. Juwenalia Górowska & $1969-1971$ \\
\hline 33. & s. M. Zbigniewa Smoleń & $1971-1977$ \\
\hline 34. & s. M. Cherubina Chudzik & $1977-1980$ \\
\hline 35. & s. M. Efrema Wielewska & $1980-1983$ \\
\hline
\end{tabular}

Łącznie: 25 sióstr przełożonych

Źródło: M.P. Lenart CSSF, Prowincja krakowska Niepokalanego Serca Najświętszej Maryi Panny Zgromadzenia Sióstr Felicjanek. Leksykon domów, t. 2: 1861-1981, cz. 5, Kraków 2004, s. 74-75.

Z powyższego zestawienia wynika, że w tarnowskim Domu ss. felicjanek pw. św. Teresy z Avila w latach 18691983 urząd przełożonej miejscowej pełniło 25 sióstr. $Z$ tego trzy siostry trzykrotnie i trzy siostry dwukrotnie.

Nadto warto wspomnieć o zajmowaniu się przez siostry felicjanki sługami żeńskimi, które zrzeszone były w Stowarzyszeniu Sług Katolickich w Tarnowie. Mieszkały w Schronisku Sług św. Zyty ${ }^{37}$. Pisano, że „zaprowadzono szkółkę niedzielną, w której 42 dziewcząt uczono czytać, pisać, rachować i robótek pod kierunkiem PP. Felicjanek. Założono biblioteczkę i gromadzono się co drugą niedzielę w ochronce u PP. Felicjanek, fundacji Sanguszków, gdzie urządzono pogadanki praktyczne dla sług. Oto krótko przedstawiona działalność Towarzystwa Sług katolickich"38.

37 Zostało ono założone przy ówczesnej ul. Topolowej, uroczyście poświęcone 24 września 1889 r., ze zorganizowanym biurem stręczeń i pralnią. Kamień węgielny pod budowę własnej realności poświęcił ks. dr J. Górka w 1906 r., a w październiku 1907 r. przeniosły się mieszkanki do ukończonego już własnego budynku, wzniesionego ze składek publicznych. Zarząd schroniska otworzył tam dla sług szkołę gotowania oraz szkołę prania i prasowania. Zob. A. Piszowa, 600 lecie Tarnowa, Tarnów 1930, s. 196.

${ }^{38}$ Z Tarnowa, „Grzmot. Katolickie Pismo Robotnicze” 1 (1896), nr 1, s. $2-3$. 


\section{Siostry Felicjanki w Tarnowie w XX wieku}

Z chwilą objęcia rządów ancilli w zakładzie sierot w Tarnowie przy ulicy Ogrodowej przez s. M. Leonę Wojtuszko w 1902 roku stosunki w tym domu zupełnie się zmieniły. Bliska bowiem znajomość s. M. Leony z księżną Konstancją Sanguszkową sprawiła, że księżna, która s. M. Leonę nie tylko ceniła, ale i kochała, dla sprawienia jej przyjemności nie tylko spełniała jej prośby , w których ona zresztą była bardzo skąpa, by nie nadużywać dobroci księżnej, ale też najchętniej załatwiała wszelkie potrzeby i ulepszenia zakładu, które sama spostrzegła lub o które spytała, będąc szczęśliwą, że może się w czymś s. Leonie przysłużyć. Była też częstym gościem na Ogrodowej i s. M. Leonę często zapraszała do siebie, do Gumnisk ${ }^{39}$. Wdzięczność dla sióstr wzrosła, gdy Bóg obdarzył księstwo długo oczekiwanym synem Romanem, przypisując to modlitwom sióstr. Z Romanem, swym synem, nigdy księżna się nie rozstawała, zasięgając u s. Leony wszelkich rad co do prowadzenia i wy-

${ }^{39}$ Niegdysiejsza podtarnowska wieś Gumniska istniała już w XV w. i od początku należała do kolejnych właścicieli Tarnowa: Leliwitów, Tarnowskich, Ostrogskich, Zamojskich, Lubomirskich, a na koniec Sanguszków, którzy w pierwszej połowie XVIII w. przenieśli tam swoją siedzibę z podupadającego zamku na Górze św. Marcina. W 1799 r. wznieśli w Gumniskach tzw. pałac letni w stylu spokojnego klasycyzmu (zach. skrzydło obecnego pałacu) wraz z towarzyszącym mu od południa ogrodem o założeniu geometrycznym w stylu „holenderskim”. Książę Władysław Sanguszko rozbudował pałac w 1834 r., dodając jego wschodnie skrzydło i piętrowy łącznik z filarowo-kolumnową galerią między skrzydłami, a wokół budynku polecił założyć rozległy ogród krajobrazowy w stylu angielskim, ze stawem-kanałem w części północnej. Później pałac wzbogacony został od zachodu o neogotycką kaplicę (ok. 1870) i od strony wschodniej o przybudówkę (ok. 1925). 
chowania dziecka ${ }^{40}$. Wielkie też było zmartwienie księżnej, gdy s. M. Leona ciężko zachorowała, a choroba parę lat trzymała ją na łożu boleści. Księżna nie szczędziła modłów ani starań i kosztów, by tylko chorej ulżyć i zdrowie przywrócić; przysyłała najlepszych lekarzy, ale wszystko zdawało się bezskuteczne. Widząc, że wszelkie zabiegi ludzkie żadnej ulgi chorej nie przynoszą, gorliwe modliła się do Boga, za przyczyną Matki Najświętszej czyniąc ślub, że jeśli Bóg wróci zdrowie ukochanej s. Leonie, odbędzie wraz z nią pielgrzymkę do Lourdes. Bóg widać przyjął tę ofiarę, bo s. M. Leona wróciła do zdrowia i razem z m. M. Kolumbą i księżną Sanguszkową odbyła na koszt księżnej dziękczynną pielgrzymkę do Lourdes. Po powrocie stamtąd s. M. Leona została przeniesiona w 1909 roku do Domu macierzystego w Krakowie na urząd sekretarki generalnej zgromadzenia. Po niej ancillą w Tarnowie była sześć lat s. M. Rajmunda, za której rządów wybuchła I wojna światowa ${ }^{41}$.

Dnia 2 kwietnia 1903 roku zmarł w Tyrolu książę Eustachy Sanguszko ${ }^{42}$. Po sprowadzeniu zwłok do Gumnisk

${ }^{40}$ [M.Ch. Jasińska], Historja Zgromadzenia SS. Felicjanek na podstawie rękopisów, cz. 3, Kraków 1932, s. 455.

${ }^{41}$ Chodzi o I wojnę światową zwaną „wielką wojną".

42 Eustachy Stanisław Sanguszko herbu Pogoń Litewska (ur. 13 lipca 1842 r. w Tarnowie lub 28 sierpnia 1842 r. w Gumniskach k. Tarnowa, zm. 2 kwietnia 1903 r. w Gries k. Bozen w Tyrolu), namiestnik Galicji, marszałek Sejmu Krajowego we Lwowie, poseł do Rady Państwa, członek Izby Panów. Nauki pobierał w Polsce oraz w Paryżu w latach 1860-1862. Studiował na Uniwersytecie Jagiellońskim w latach 1862-1864. Posiadał majątki ziemskie: Podhorce i Gumniska. Był posłem na Sejm Krajowy we Lwowie (od 1873 r.), marszałkiem Sejmu Krajowego we Lwowie w latach 1890-1895, posłem do Rady Państwa V kadencji w latach 1873-1879, członkiem Izby Panów od 20 września 1879 r. i namiestnikiem Galicji od 25 września 1895 r. do marca 1898 r. Wniósł duże zasługi w rozwój 
siostry z obydwóch domów wraz z dziećmi wzięły udział w nabożeństwie i obrzędzie pogrzebowym. Po s. M. Benwenucie, która rok tylko była na Grabówce, została ancillą na cztery lata m. M. Baptysta, po niej dwa lata s. M. Magdalena, potem trzy lata m. M. Benedykta, a wreszcie dziewięć lat z przerwami s. M. Perpetua. Ksiądz infułat Walczyński po długiej i ciężkiej chorobie zmarł podczas inwazji rosyjskiej 2 lutego 1915 roku. Jak dalece był szanowany i kochany przez ogół mieszkańców Tarnowa, dowodzi to, że nie zważając podczas działań wojennych na huk armat i strzelaninę, całe niemal miasto wyszło na pogrzeb, odprowadzając zwłoki zasłużonego kapłana na miejsce wiecznego spoczynku. Siostry straciły w nim prawdziwego opiekuna i przyjaciela.

\section{Dom św. Stanisława BM (8 grudnia 1900 - 29 czerwca 1955) - Ochronka na Grabówce}

Oprócz zakładu sierot powstała w Tarnowie w 1901 roku na przedmieściu zwanym „Grabówka” ochronka ze składek osób dobroczynnych. Największą ofiarę złożyli na ten cel książęta Roman i Eustachy Sanguszkowie. Natomiast znaczną rolę w powstaniu tejże placówki odegrał ks. infułat Stanisław Walczyński ${ }^{43}$. Ochronkę na sieci transportowej w Galicji. W swojej polityce kierował się zasadą konserwatyzmu. Działał aktywnie w Towarzystwie Tatrzańskim, do którego należał od 1875 r. W latach 1885-1890 był jego prezesem, a w 1891 r. został jego członkiem honorowym. Był synem Władysława Hieronima, bratem Romana Damiana i Pawła Romana. Jego żoną od 1895 r. była Konstancja Anna Maria hr. Zamoyska z Zamościa herbu „Jelita”. Miał syna Romana. Pochowany został w rodzinnym majątku w Gumniskach. Por. S. Kieniewicz, Sanguszko Eustachy Stanisław, [w:] Polski słownik biograficzny, t. 34/4, z. 143, red. H. Markiewicz, Wrocław-WarszawaKraków 1993, s. 478-480.

${ }^{43}$ [M.Ch. Jasińska], Historja Zgromadzenia..., cz. 3, dz. cyt., s. 456. 
Grabówce ${ }^{44}$ wybudował budowniczy Szczęsny Zaremba w $1900 \mathrm{roku}^{45}$. Pierwotnie miano zamiar oddać ochronkę w zarząd siostrom służebniczkom i dla ich potrzeb ochronkę tę dostosowano, stąd też część mieszkalna była niewielka, lecz księżna Konstancja Sanguszkowa, bardzo przychylna zgromadzeniu felicjanek, zażądała stanowczo sprowadzenia do ochronki sióstr felicjanek. Matka generalna Magdalena przychyliła się do jej prośby i posłała dwie siostry chórowe i dwie siostry konwerski ${ }^{46}$, a na pierwszą ancillę s. M. Benwenutę Kłódkowską, które zanim się urządziły w nowym domu, zamieszkały tymczasowo u sióstr w Domu św. Teresy z Avila przy ul. Ogrodowej. Dnia 8 grudnia 1901 roku odbyło się poświęcenie domu pod wezwaniem św. Stanisława BM, a 29 grudnia tego samego roku miała miejsce pierwsza msza święta i zaprowadzenie Sanctissimum w malutkiej kapliczce, dobudowanej staraniem głównie ks. inf. Walczyńskiego ${ }^{47}$, na którą książę

44 Grabówka była dawniej wsią, w 1846 r. została przyłączona do Tarnowa, obejmując obszar od północno-wschodniej strony centrum miasta. Zob. J. Kozioł, A. Niedojadło, M.K. Trusz, Grabówka, [w:] Encyklopedia Tarnowa, dz. cyt., s. 141-142.

45 Siostry Felicjanki prowadziły ochronkę na Grabówce do około 1950 r. Por. Domy sierot i dziecka. Ochronka na Grabówce, [w:] Grabówka, red. S. Potępa, Tarnów 2006, s. 157, seria Tarnów. Wielki przewodnik, t. 14.

${ }^{46}$ Siostry dzieliły się na chórowe i martanki (później zwane konwerskami).

${ }^{47}$ Walczyński Stanisław (ur. 24 sierpnia 1841 r. w Żywcu, zm. 2 lutego 1915 r. w Tarnowie), kapłan rzymskokatolicki, działacz społeczny, nauczyciel i ojciec duchowny, wicerektor w tarnowskim Seminarium Duchownym, katecheta w c.k. gimnazjum w Tarnowie, kanclerz kurii diecezjalnej, od 1890 r. prepozyt infułat kapituły katedralnej. W 1909 r. wybrany wikariuszem kapitulnym, administrował diecezją tarnowską po śmierci bpa A. Pukalskiego. Od 1885 r. protonotariusz apostolski. 
Eustachy Sanguszko ofiarował 1200 koron. Po mszy świetej ks. inf. Walczyński przemówił bardzo serdecznie do licznie zgromadzonego ludu, zachęcając do posyłania dzieci do ochronki celem uchronienia ich od zgubnego wpływu ludności żydowskiej ${ }^{48}$, a także do gromadzenia się na msze święte i nabożeństwa, jakie w tej kaplicy będą odprawiane. Na dalsze urządzenie domu zebrano składkę w kwocie przeszło 200 koron. Dobroczynne panie z Bractwa Różańcowego, którego prezesem był ks. inf. Walczyński, a prezesową księżna Sanguszkowa, zajęły się sprawieniem i szyciem ubrań dla biednych dzieci i ubraniem drzewka, a w Świętych Młodzianków (28 grudnia) same rozdzielały dary dla 130 ubogiej, uszczęśliwionej dziatwy. Odtąd rokrocznie tak je obdarzały, by zachęcić dzieci do jak najliczniejszego uczęszczania do ochronki. Przez zbieranie zaś funduszu żelaznego ks. Walczyński przyczynił się do rozdawania obiadów dzieciom w ochronce, $z$ którego ofiarowywał 80 koron miesięcznie. Utrzymanie sióstr zapewniał magistrat miasta Tarnowa, wypłacając rocznie 2 tys. koron, głownie dzięki staraniom ks. inf. Walczyńskiego, uważanego za opiekuna i dobrodzieja tak podopiecznych dzieci, jak i sióstr. Kapłan ten bardzo często odprawiał w kapliczce mszę świętą, głosząc przy tym naukę, na którą licznie gromadziła się miejscowa ludność. Dzięki Opatrzności Bożej dom sióstr nie spłonął podczas dwukrotnego pobliskiego pożaru ${ }^{49}$. W 1901 roku ofiarował się na codzienne odprawianie mszy świętej, mimo znacznej odległości od mia-

Por. K. Moskal, Walczyński Stanisław, [w:] Encyklopedia Tarnowa, dz. cyt., s. 479 .

${ }^{48}$ Grabówkę zamieszkiwali wówczas przeważnie tarnowscy Żydzi.

${ }^{49}$ Encyklopedia Tarnowa, dz. cyt., s. 457. 
sta, ks. Józef Koterbski, katecheta szkoły ludowej, i stale przez dwa lata ją odprawiał, dopóki nie został przeniesiony. Duchowieństwo tarnowskie, bardzo przychylne zgromadzeniu, chętnie ofiarowało się na odprawianie mszy świętych i innych nabożeństw w kaplicy, także majowego, czerwcowego i różańcowego. Przez z górą 20 lat odprawiał codziennie mszę świętą ks. Stanisław Dutkiewicz ${ }^{50}$, profesor tarnowskiego Seminarium Duchownego, który otaczał siostry ojcowską opieką. Z jego inicjatywy i starania magistrat tarnowski zakupił dla sióstr niewielki grunt (około $3 / 4$ morga), przylegający do ochronki, przewidziany pod jarzyny, który ksiądz swoim kosztem ogrodził. Pierwotnie ziemię tę miał kupić Żyd i urządzić tam zajazd dla koni ${ }^{51}$. Stąd też wzięła swoją nazwę ulica Ochronek, która funkcjonuje do dnia dzisiejszego.

Mieszkańcy Grabówki była to najuboższa ludność, klasa wyrobnicza, pozostająca w wielkiej nędzy materialnej i moralnej, wyzyskiwana przez Żydów, wśród których prze-

${ }^{50}$ Dutkiewicz Stanisław Jan (ur. 17 kwietnia 1862 r. w Zakliczynie, zm. 26 III marca 1926 r. w Tuchowie), kapłan rzymskokatolicki wyświęcony w 1886 r., studiował prawo kanoniczne na Gregorianum, uwieńczone w 1888 r. doktoratem; w latach 1888-1897 był wychowawcą i ojcem duchownym w Seminarium Duchownym w Tarnowie. Proboszcz w Żegocinie (1897-1904), organizował kółka rolnicze, spółdzielnię mleczarską i popierał rozwój sadownictwa. W latach 1904-1921 był rektorem seminarium, zreorganizował kształcenie i wychowanie przyszłych kapłanów, odrestaurował gmachy, wybudował dom wypoczynkowy, dbał o bibliotekę dla duchowieństwa zajmującego się pracą duszpasterską. Dnia 5 września 1922 r. został instytuowany na probostwo w Tuchowie. Odznaczony EC w 1875 r., RM 15 sierpnia 1891 r. Spoczywa na cmentarzu w Tuchowie. Por. B. Kumor, Dutkiewicz Stanisław, [w:] Encyklopedia katolicka, t. 4, Lublin 1983, kol. 399.

${ }^{51}$ Encyklopedia Tarnowa, dz. cyt., s. 458. 
bywała. Toteż ważną rolę odegrała ochronka, jak również kapliczka, ściągająca liczne grono tychże ubogich, którzy by z pewnością do kościoła nie uczęszczali. Zło jednak wkorzenione i zastarzałe tak łatwo wyrwać się nie dało, trzeba było użyć do tego działań umoralniających w postaci misji, urządzonych staraniem kapituły tarnowskiej na propozycję ks. prałata F. Leśniaka, ówczesnego proboszcza jedynej w Tarnowie parafii. Urządzono je w ochronce wyłącznie dla Grabówki, uprzednio ogłaszając to $\mathrm{z}$ ambon tarnowskich kościołów. Trwały one pięć dni. Przeprowadzili je dwaj ojcowie redemptoryści z krakowskiego Podgórza, którzy głosili po cztery nauki dziennie. $Z$ wielkim zapałem już od czwartej rano gromadzili się mieszkańcy przedmieścia na godzinki, nauk słuchali w ciszy i z wytężoną uwagą. Nie obliczono dokładnie, ilu wiernych brało udział w misji, w każdym razie nie było ich mniej jak tysiąc, bo tyle rozdano Komunii świętych. Ostatniego dnia biskup tarnowski odprawił mszę świętą na werandzie i 300 osobom udzielił sakramentu bierzmowania. Jak komentowano - podobnie uroczystego nastroju nikt jeszcze na Grabówce nie widział. Na pamiątkę tych dni mieszkańcy postawili przed ochronką wielki krzyż dębowy, uroczyście poświęcony przez księdza infułata, i zapalili przed krzyżem wieczystą lampkę. Tam przychodzili się modlić codziennie; tam też dokonywały się piękne akty pojednania zwaśnionych i przebaczania uraz. Podczas II wojny światowej Grabówka, podobnie jak okolice Rynku zamieszkałe w większości przez Żydów, wyludniły się.

W czasach reżimu komunistycznego ówczesna władza PRL siłą i przemocą zabrała wielu zgromadzeniom zakonnym ich nieruchomości, w tym i siostrom felicjan- 
kom budynek przy ul. Lwowskiej 52 (ówczesnej Stalina $52)^{52}$. Zachowały się archiwalia $\mathrm{z}$ tamtego okresu, będące dowodami na ówczesne niegodziwości komunistyczne. Decyzję o wyeksmitowaniu, czyli wygnaniu sióstr z tegoż budynku wydał 24 września 1954 r. Wydział Gospodarki Komunalnej i Mieszkaniowej Powiatowej Rady Narodowej w Tarnowie L. dz. GKMK-2a/1773/54, a Komisja Lokalowa WRN w Krakowie 24 kwietnia 1955 r. ją zatwierdziła. Siostry wnosiły odwołania, zażalenia na krzywdzącą decyzję. Argumentowały m.in., że: „Zgromadzenie Sióstr Felicjanek $\mathrm{w}$ Tarnowie zostało wyeksmitowane $\mathrm{z}$ budynku klasztornego mieszczącego się w Tarnowie przy ul. Stalina 52, w którym po objęciu przedszkola przez organa miejskie zajmowało dwie ubikacje mieszkalne na poddaszu. (...) Zajmowały je przez 50 lat. Prowadzily w interesie miasta Tarnowa prace charytatywne i wychowawcze nad miejscową młodzieżą". „Jednocześnie z likwidacją naszego mieszkania (...) została zlikwidowana znajdująca się w przedmiotowym domu od 50 lat kaplica publiczna, z której każdego dnia, każdej niedzieli i w każde święto nie dziesiątki, ale setki ludzi korzystało". „Zgromadzenie (...) zostało w brutalny sposób wyrzucone z zajmowanego lokalu, przy pomocy organów U.B. oraz M.O. i przymusowo odtransportowane do Krakowa" ${ }^{3}$. Jednakże Wojewódzka Komisja Lokalowa w Krakowie była bezwzględna, realizowała wytyczne ówczesnych władz, wydając decy-

${ }^{52} \mathrm{O}$ tym, że czasowo przemianowano ul. Lwowską na ul. Stalina, nie wspomniano w ogóle w Encyklopedii Tarnowa. Por. L. Błaszkiewicz, Lwowska ulica, [w:] Encyklopedia Tarnowa, dz. cyt., s. 246.

${ }^{53}$ ADT, zespół Felicjanki-Zgromadzenie Sióstr Św. Feliksa z Kantalicji (CSSF), t. 1, lata 1947-2000, sygn. ZŻ/1, Pismo odwoławcze SS. Felicjanek, k. 2. 
zję 20 czerwca 1955 r. oddalającą zażalenie sióstr na orzeczenie nr OL IV/T-114/5554. Jak ówczesna władza obchodziła się z osobami duchownymi, świadczy pisemna relacja jednej z sióstr felicjanek: „Kaplicę na Grabówce w tej chwili zajęli, mnie przemocą wypędzili na ulicę. Klucz od kaplicy mam u siebie. W tej chwili jestem na Rzędzinie. Matkę [przełożoną] o 10-tej wezwali do Wyznań Religii [Referat ds. Wyznań MRN w Tarnowie]"55. Szczególnym aktywistą PZPR-owskim był w tym względzie niejaki Z. Mendysa, kierownik Referatu ds. Wyznań w Tarnowie, który ignorując nawet ówczesne komunistyczne prawo, usiłował wezwać ks. prof. Leopolda Regnera na przesłuchanie. Kapłan ten napisał obszerne zażalenie na działalność Z. Mendysa, który wystawił mu wezwanie 20 minut (!) przed terminem stawienia się w urzędzie, grożąc księdzu w konsekwencji zlikwidowaniem kaplicy katolickiej przy ul. Stalina $52^{56}$. O zajściach w budynku przy ul. Stalina 52 informował pisemnie na bieżąco Kurię biskupią w Tarnowie ks. Stefan Dobrzański z kościoła i parafii Najświętszego Serca Jezusowego na Rzędzinie: „30 VI 1955 r. w godzinach od 14:30 do 19. Prezydium MRN w Tarnowie dokonało eksmisji Sióstr Felicjanek zam. przy ul. Stalina 52. Rzeczy zostały załadowane na auta - cztery siostry zakonne, które opiekowały się kaplicą św. Stanisława BM zostały autem przewiezione do Krakowa na ul. Smoleńską"57. I kolej-

${ }^{54}$ Tamże, Postanowienie Wojewódzkiej Komisji Lokalowej w Krakowie z 20 VI 1955 r. oddalające zażalenie SS. Felicjanek w Tarnowie, b. numeracji.

55 Tamże, Oświadczenie pisemne S. Felicjanki [nieczytelny podpis] z 8 VII 1955 r., b. numeracji.

${ }^{56}$ Tamże, Zażalenie ks. prof. Leopolda Regnera na Z. Mandysa z 7 VII 1955 r., b. numeracji.

57 Tamże, Pismo z 1 VII 1955 r. Urzędu parafialnego przy kościele N.S.J. w Tarnowie do Kurii biskupiej w Tarnowie, L. p. 166/55. 
na informacja: „8 VII 1955 r. o godz. 10-tej pewni osobnicy najprawdopodobniej z Prezydium MRN w Tarnowie dokonali zamknięcia kaplicy przy ul. Stalina 52 - podstępem i siłą usuwając siostrę zakonną, która przebywała w zakrystii. (...) Interwencja w Referacie Wyznań w godz. popołudniowych nie dała żadnego wyniku. (...) Do godz. 23. wierni pilnowali czy kaplicy nie będą ruszać. Dziś rano wierni zgromadzili się na chodniku i długo oczekiwali, niestety furtki na podwórze nie otworzono. (...) Na miejsce sióstr zakonnych sprowadzono nauczyciela z rodziną najprawdopodobniej z Zalipia"58. Siostry felicjanki wielokrotnie pisemnie wnosiły do władz prośby o zwrot ich własności, jednakże bezskutecznie ${ }^{59}$. Interpelacje wnosili również ówcześni posłowie. Niestety ślepy fanatyzm, głupota i służalczość komunistycznych nadgorliwych aktywistów wzięły górę.

\section{Budynek przy ul. gen. J. Bema 14}

Dom i parcela o ogólnej powierzchni 47 morgów i $89 \mathrm{~m}^{2}$ przy ul. Ogrodowej w Tarnowie były własnością sióstr felicjanek na podstawie postanowienia Sądu Powiatowego w Tarnowie z 15 czerwca 1957 roku $^{60}$. Budynek przedstawiał się wówczas następująco: był to dom piętrowy, w którym siostry prowadziły: zakład dla sierot, ochronkę, pracownię szat liturgicznych, niedzielną szkołę dla służących i aż do 1956 roku przedszkole. Od 1956 roku mieścił się

58 Tamże, Pismo z 9 VII 1955 r. ks. Stefana Dobrzańskiego do Kurii biskupiej w Tarnowie, b. numeracji.

${ }_{59}$ Tamże, Wniosek SS. Felicjanek o zwrot kaplicy, przedszkola i lokalu mieszkalnego w Tarnowie przy ul. Stalina 52, b. numeracji.

${ }^{60}$ Por. Archiwum Sądu Rejonowego w Tarnowie, Wydział VI Ksiąg Wieczystych, Postanowienie Sądu Powiatowego w Tarnowie z 15 VI 1957 r., DKW 831/57. 
tam Zakład Wychowawczy Caritas ${ }^{61}$ dla dziewcząt upośledzonych umysłowo w stopniu lekkim (debilizm). Nadto była tam kaplica z pełnym wyposażeniem. Dom ten był wielokrotnie odnawiany, odrestaurowywany, ale mury miał słabe, od fundamentów (zwłaszcza od strony południowej) zawilgocone. W piwnicach był magazyn na artykuły i produkty żywnościowe, a na parterze korytarz z klatką schodową, kaplica, zakrystia, przedpokój i pokój dla personelu świeckiego (dwóch pomocnic kuchennych), rozmównica (a w niej cela dla siostry kucharki). Cela ta była zupełnie oddzielona wysokim stałym drewnianym parawanem z zamykanymi na klucz drzwiami; poza tym refektarz, kuchnia, pomieszczenie na szafę chłodniczą. Na piętro było dodatkowe wejście od podwórka i znajdowały się tam: ustępy i łazienka dla zakładowych dzieci, szatnia, cztery sale sypialne dla dzieci, salka higieniczna - izolatka dla chorych dzieci, korytarz, pracownia haftów (w niej cela dla jednej siostry). Z pracowni przechodziło się do pracowni krawieckiej, dalej dormitarz dla czterech sióstr oddzielony parawanami. Strona południowa wysokiego i obszernego strychu została wykorzystana na wybudowanie i urządzenie dalszych cel dla sióstr. Korytarze wykorzystano na umieszczenie szaf i walizek. W podwórzu mieściły się: pralnia, świetlico-uczelnia z małą szatnią. Za uczelnią do odrabiania lekcji szkolnych służyły również jadalnie - większa i mniejsza, w głównym budynku na parterze. Po drugiej stronie podwórza były stare pomieszczenia gospodarcze: drewutnia i szopa na węgiel, kurnik i chlewik, magiel i stara pralnia. Od strony południo-

${ }^{61}$ Nie była to organizacja Caritas kościelna, ale świecka o nazwie: Zrzeszenie Katolików Caritas. 
wej był plac zabaw dla dzieci. Na środku placu - piękna duża figura Matki Bożej Niepokalanej. Za placem był ogród sióstr. W 1965 roku w domu mieszkało 12 sióstr i były to:

s. Zbigniewa Smoleń - przełożona, katechetka szkoły specjalnej (24 godziny tygodniowo)

s. Restytuta - lat 70 - wikaria - praca w parafii katedralnej (opiekunka rejonowa), układanie bielizny

s. Berchmansa - lat 78 - chora

s. Ambrozja - lat 53 - kucharka

s. Witolda - lat 45 - księgowa

s. Archangela - lat 38 - wychowawczyni

s. Świętosława - lat 39 - wychowawczyni

s. Efrema - lat 40 - kierowniczka zakładu dla debilów

s. Ildefonsa - lat 40 - wychowawczyni

s. Antonetta - lat 27 - ogrodniczka

s. Józafata - lat 45 - szaty liturgiczne (szycie, naprawa)

s. Paschalisa - lat 24 - krawcowa

Siostry prowadziły zakład dla niedorozwiniętych dzieci (dziewczynek). Miały pod opieką 50 dzieci w wieku 8-18 lat. Prowadziły też pracownię paramentów liturgicznych. Od 1961 roku był tylko jeden chór sióstr. Wizytujący dom i siostry ks. kanonik mgr Stanisław Wójtowicz zanotował: „Siostry mają pewne trudności ze starym budynkiem, który wciąż wymaga konserwacji i naprawy. Dokuczają im ciągłe wizytacje, drobiazgowość i biurokracja"62.

Stan personalny domu tarnowskiego w 1974 roku przedstawiał się następująco:

${ }^{62}$ ADT, zespół Felicjanki-Zgromadzenie Sióstr Św. Feliksa z Kantalicjo (CSSF), t. 1, lata 1947-2000, sygn. ZŻ/1, Sprawozdanie z wizytacji Domu filialnego SS. Felicjanek w Tarnowie, ul. Focha 16 przeprowadzonej w czerwcu 1965 r. [przez ks. kan. mgr S. Wojtowicza], b. numeracji. 


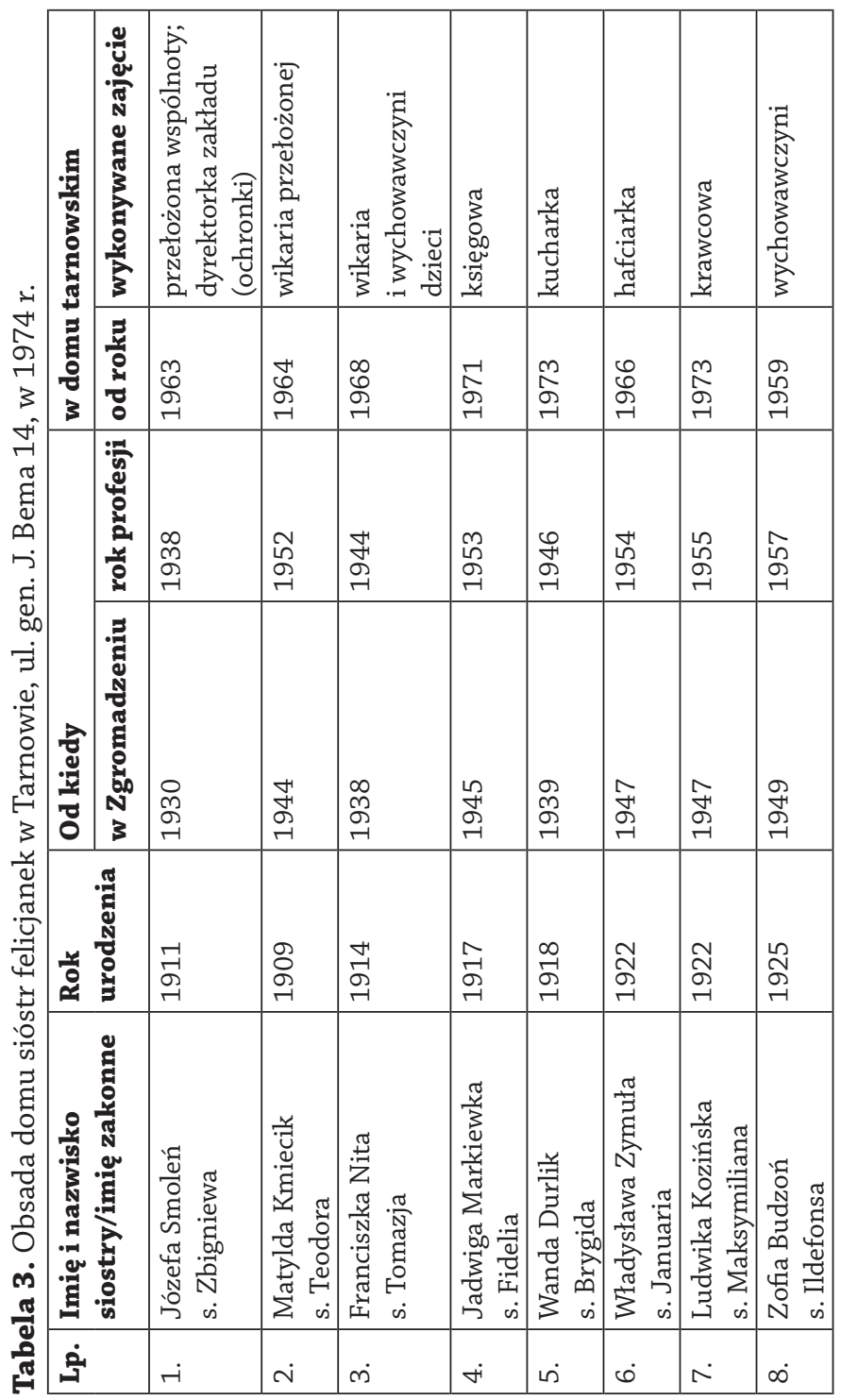

192 . Paweł Glugla 


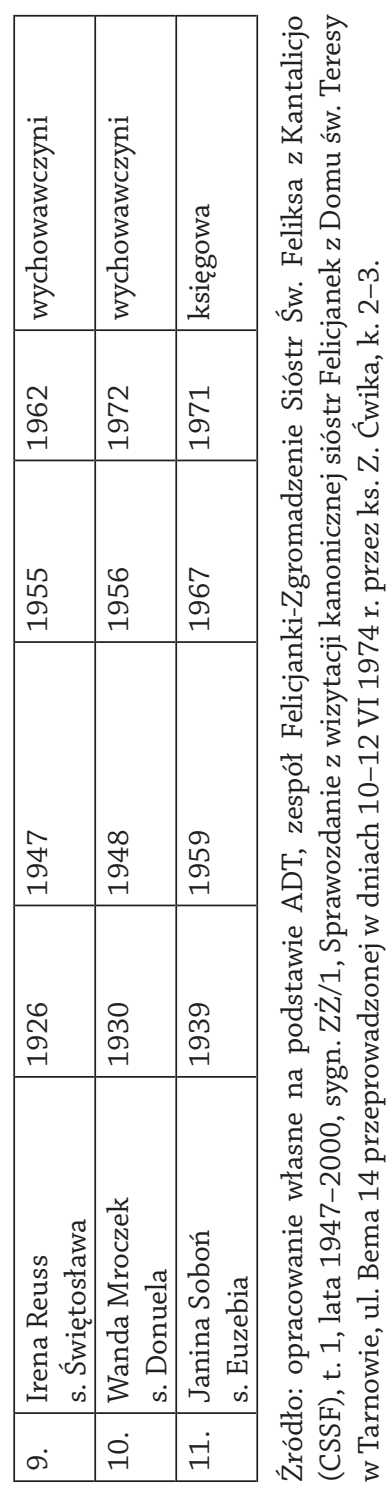

Zgromadzenie Sióstr Felicjanek w Tarnowie... 193 
Jak widać, w 1974 roku w domu tarnowskim przy ul. gen. J. Bema 14 mieszkało i pracowało 11 sióstr felicjanek. Pośród nich była przełożona (a zarazem dyrektorka ochronki zwanej zakładem), dwie wikarie, a także trzy wychowawczynie dzieci, dwie księgowe, hafciarka, kucharka. Wiek sióstr wahał się od 35 do 63 lat, dając średnią wieku 52,8. W 1974 roku najdłuższy staż zakonny w tarnowskim domu miała s. Ildefonsa (15 lat), a najkrótszy s. Brygida (jeden rok).

W domu tym nie było formalnie siostry furtianki, stąd co jakiś czas dochodziło do kradzieży. Drzwi wejściowe nie były w ciągu dnia zamykane na klucz z uwagi na częste przemieszczanie się podopiecznych, ubogich. Należy nadmienić, że siostry z tego domu prowadziły dodatkowo katechizację w parafii katedralnej.

\section{Praca w Tarnowie przy ul. Krakowskiej 39}

Od 1903 roku w budynku (dworku) usytuowanym na Strusinie przy ul. Krakowskiej 39, ofiarowanym przez Sanguszków księżom misjonarzom, mieściła się ochronka pw. św. Józefa, prowadzona najpierw przez siostry felicjanki, następnie służebniczki NMP NP starowiejskie i na końcu przez siostry miłosierdzia (szarytki). Budynek ten istniał prawie 170 lat (rozbiórka jego nastąpiła w 1974 roku). Sanguszkowie mieszkali w pałacu-rezydencjiw Gumniskach. W ochronce tej, będącej pod zarządem Stowarzyszenia Pań Miłosierdzia i księży misjonarzy, posiadającej statut wydany przez zarząd województwa krakowskiego, otaczano opieką dzieci od 3 do 7 lat w czterech pomieszczeniach, w tym były dwie sale naukowe oraz kuchnia. Proboszcz parafii Świętej 
Rodziny w Tarnowie ks. dr J. Gaworzewski CM w 1918 r. informował lokalny Konsystorz biskupi o dziełach charytatywnych, w tym o ochronce św. Józefa:

założona została staraniem Zgromadzenia XX. Misjonarzy w Tarnowie na Strusinie ochronka p.w. św. Józefa. XX. Misjonarze kierują ochronką przy pomocy komitetu Pań w celu zbierania składek. Ochronka mieści się w domu, który jest własnością Zgromadzenia Misji, na użytek dziatwy ochronki odstąpiło Zgromadzenie XX Misjonarzy część swojego ogrodu. Liczba uczęszczających dzieci do wzmiankowanej ochronki dochodzi w porze letniej do 20, w porze zimowej dosięga połowy tej cyfry, wiele bowiem dzieci pozbawionych jest cieplejszego ubrania i obuwia. Źródłem dochodów ochronki są datki prywatne, zbierane zapobiegliwie przez komitet Pań oraz także w małej części z subwencji różnych instytucji finansowych. Na początku istnienia ochronki pewną kwotę udzieliło CK Namiestnictwo, pewien także datek na cel powyższy składa Tarnowska Kasa Oszczędności oraz c.k. Dyrekcja Kolei Państwowych $(400 \text { k. })^{63}$.

Należy dodać, że ks. Andrzej Balicki CM (z księży misjonarzy w Tarnowie) na pisemny wniosek przełożonej prowincjalnej sióstr felicjanek był spowiednikiem zwyczajnym sióstr felicjanek domu filialnego w Tarnowie w latach 1953-1953 ${ }^{64}$.

${ }^{63}$ Por. ADT, Akta lokalne parafii. Parafia Tarnów św. Rodziny 18971946, sygn. LT XIII, Pismo ks. J. Gaworzewskiego do Konsystorza biskupiego z 6 III 1918 r., b. sygn.

${ }^{64}$ ADT, zespół Felicjanki-Zgromadzenie Sióstr Św. Feliksa z Kantalicjo (CSSF), t. 1, lata 1947-2000, sygn. ZŻ/1, Wniosek przełożonej SS. Felicjanek w Krakowie z 5 X 1950 r. do Kurii biskupiej w Tarnowie o zamianowanie ks. A. Balickiego CM spowiednikiem zwyczajnym SS. 


\section{Zakończenie}

Siostry felicjanki sprowadziła do Tarnowa w 1869 roku księżna Izabela Sanguszkowa, oddając im zakład sierot przy ówczesnej ul. Chyszowskiej. W 1873 roku cztery siostry felicjanki pracowały w tarnowskim szpitalu cholerycznym. Zakład sierot z około 30 dziewczynkami został w 1894 roku przeniesiony na Strusinę (obecnie ul. gen. J. Bema 14$)^{65}$. Po II wojnie światowej przekształcono go początkowo $w$ dom dziecka, a w 1952 roku w zakład wychowawczy dla dziewcząt z lekkim upośledzeniem. Drugi dom felicjanek powstał w 1900 roku przy ul. Lwowskiej 52. Siostry prowadziły tam ochronkę i przedszkole. W czasie II wojny światowej w domu tym urządzono kuchnię dla ubogich. W 1949 roku władze oświatowe odsunęły siostry od pracy w przedszkolu, dlatego podjęły one w latach 1951-1954 katechizację. W 1955 roku komuniści zlikwidowali kaplicę, a siostry zmuszono do opuszczenia domu zakonnego. Felicjanki pozostały w Tarnowie, tylko w domu przy ul. gen. J. Bema 14, który został zamknięty w 1992 roku $^{66}$. Aktualnie swoją siedzibę w tym budynku ma diecezjalne Radio Dobra Nowina (RDN). Nadto jakiś czas siostry prowadzily ochronkę w budynku posanguszkowskim przy ul. Krakowskiej 39. Siostry felicjanki

domu filialnego w Tarnowie, ul. Focha 14 na pierwsze trzechlecie, L. OZ.II-10/13/50; tamże Zgoda Kurii biskupiej w Tarnowie z 10 X 1950 r.

${ }^{65}$ Zob. Zakład Sierot im. księżnej Izabeli Sanguszkowej ss. Felicjanek, [w:] Tarnów. Strusina 19. Wielki Przewodnik, red. S. Potępa, Tarnów 2009, s. 75-77. Przedruk za: A Piszowa, Zakład Sierót im. księżnej Izabeli Sanguszkowej, „Pogoń” 20 (1900), nr 29 z 11 IV.

${ }^{66}$ R. Biel, Zgromadzenie Sióstr Świętego Feliksa z Kantalicjo Trzeciego Zakonu Regularnego Świętego Franciszka Serafickiego, Felicjanki, [w:] Encyklopedia Tarnowa, dz. cyt., s. 528. 
znane były w Tarnowie i diecezji tarnowskiej, a nawet całej Polsce z artystycznego haftu paramentów liturgicznych (w tym ornatów, kap, dalmatyk, chorągwi, baldachimów itp.). Korzystali z ich usług m.in. księża misjonarze, oddając do odnowienia ornaty, stuły ${ }^{67}$, kapy ${ }^{68}$. Urządzały okresowo wystawy swoich dzieł, a po ich zakończeniu nierzadko obdarowywały ubogie kościoły i parafie w najpotrzebniejsze liturgiczne przedmioty powystawowe ${ }^{69}$. Nadto chętnie żmudnie naprawiały i odnawiały sprzęty liturgiczne, pobierając w zamian niewielką opłatę. Szyły również klerykom sutanny, od mniej zamożnych pobierając tylko równowartość kosztu materiału, zaś ubogim sutanny sprawiały gratisowo. Przeprowadzane wizytacje domów sióstr felicjanek wypadały zawsze bardzo pozytywnie.

Podsumowując, należy zaznaczyć, że doceniali je biskupi tarnowscy, a wśród nich bp J. Ablewicz, który publicznie stwierdził, że „nieraz Zgromadzenie Sióstr Felicjanek było wystawiane na rozmaite kłopoty materialne. Dzieci, sieroty, biedaków - o czym się dzisiaj tak często zapomi-

67 Wpis pod datą 20 maja 1930 r. w kronice parafialnej Księży Misjonarzy w Tarnowie: „Odnowiono u SS. Felicjanek w Tarnowie kilka ornatów i stuł”. Por. Archiwum Księży Misjonarzy w Tarnowie (dalej: AKMT), Kronika parafii, t. 1, s. 29.

${ }^{68}$ W dniu 2 września 1930 r. odnowiono dwie kapy i dwa ornaty. Por. AKMT, Kronika parafii, t. 1, s. 31.

${ }^{69}$ Były to liturgiczne paramenty po wystawie, która miała miejsce w klasztorze sióstr felicjanek w Tarnowie przy ul. Ogrodowej w dniach 27-29 września 1911 r. Zob. Kronika miejscowa i zamiejscowa Tarnów 23 IX 1911, Arcybractwo nieustającej Adoracji Najśw. Sakramentu, „Pogoń” 31 (1911), nr 39, s. 4. 
na - utrzymywały z ciężkiej pracy, z ogromnego wysiłku"70. A w dniu 30 grudnia 1969 roku tenże biskup ordynariusz tarnowski powiedział: „Pracowały najpierw na Strusinie, później przy Ogrodowej, na Grabówce przy ul. Lwowskiej, skąd ich w niesprawiedliwy, krzywdzący sposób osunięto. I mają tak po ludzku sądząc wspaniałą opinię w Tarnowie. Opinię wypracowaną dziesiątkami lat. (...) Domy sióstr Felicjanek w Tarnowie miały szczęście do dobrych przełożonych"71. Siostry felicjanki przez pracowite 123 lata pobytu w Tarnowie prowadziły wiele dzieł tak materialnych, jak i duchowych. Pozostały po nich archiwalia, które świadczą o ich wielkim zaangażowaniu w życie tarnowskiego Kościoła i społeczeństwa.

${ }^{70}$ ADT, zespół Felicjanki-Zgromadzenie Sióstr Św. Feliksa z Kantalicji (CSSF), t. 1, lata 1947-2000, sygn. ZŻ/1, Przemówienie [z 28 grudnia 1969 r.] bpa J. Ablewicza wygłoszone w katedrze tarnowskiej z okazji uroczystości 100-lecia przybycia do Tarnowa Sióstr Felicjanek, mps, k. 6.

${ }^{71}$ Tamże, Przemówienie J.E. Ks. Bpa Ordynariusza [J. Ablewicza] wygłoszone z okazji uroczystości 100-lecia przybycia i pracy sióstr Felicjanek w Tarnowie, k. 5. 